\title{
REPRESENTAÇÕES E PRÁTICAS DE CONSUMO NO MEIO RURAL
}

MARIA ELISA DE PAULA EDUARDO GARAVELLO

Orientadora: MARIA IGNEZ GUERRA MOLINA

Dissertação apresentada à Escola Superior de Agricultura "Luiz de Queiroz", da Universidade de São Paulo, para obtenção do título de Mestre em Sociologia Rural.

PIRACICABA

Estado de São Paulo - Brasil

Outubro - 1982 
A meus pais 


\section{AGRADECIMENTOS}

A Prof ${ }^{\mathrm{a}}$ Dra Maria Ignez Guerra Molina, pelas observações, crīticas e sugestões, alēm do constante estīmulo na orientação deste trabalho.

A Prof $\stackrel{\text { a }}{\text { Dra }}$ Maria Dulce Bandiera Bergamin, que acompanhou de perto todos os estágios de elaboração deste trabalho, pelo interesse, sugestões e incentivo nos momentos de desānimo e insegurança.

A Prof $\stackrel{\mathrm{a}}{ }$ Dr a Maria de Lourdes T.B. Wiendl pelas valiosas sugestões e observações feitas à leitura dos originais.

Ao Prof. Dr. Oriowaldo Queda pela efetiva contribuição na fase inicial deste trabalho.

Ās colegas do Curso de Graduação em Economia Doméstica pelo estímulo e confiança em mim depositada.

A Sra. Elisa da Silva Peron pela colaboração na fase de impressão deste trabalho.

A todas as pessoas que direta ou indiretamente contribui ram para que este trabalho se concretizasse. 
INDICE

Pāgina

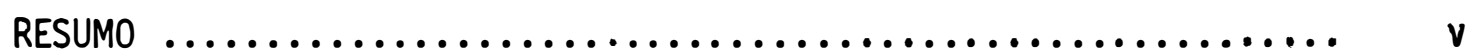

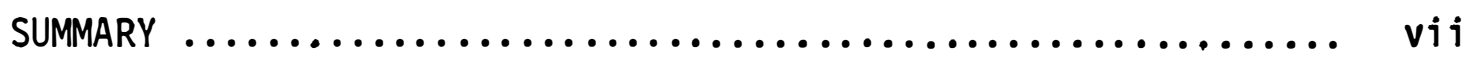

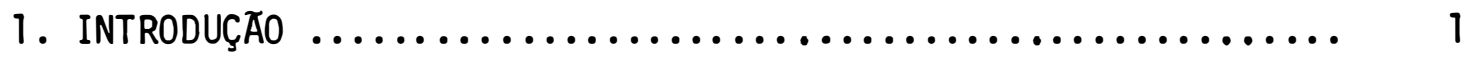

2. CONDIÇסES MATERIAIS DE EXISTENCIA $\ldots \ldots \ldots \ldots \ldots \ldots \ldots \ldots \ldots$

3. SUBORDINAÇÃO E SIGNIFICADO $\ldots \ldots \ldots \ldots \ldots \ldots \ldots \ldots \ldots \ldots \ldots \ldots \ldots \ldots \ldots \ldots \ldots$

3.1. Relações cidade-campo ..................... 17

3.2. A Dimensão Cultural ou Simbōlica ................ 23

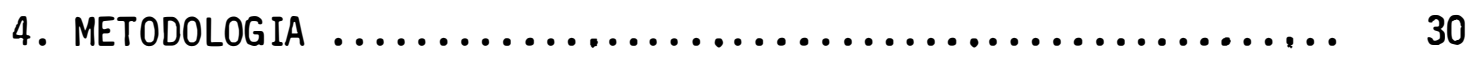

4.1 . Objetivos .............................. 30

4.2. Definição da Amostra ........................ 34

4.3. Coleta de Dados ................................ 36

5. ANÁLISE E DISCUSSÃO DOS RESULTADOS $\ldots \ldots \ldots \ldots \ldots \ldots \ldots \ldots . \ldots \ldots$

5.1. Caracterização da População .................... 39

5.2. As Representações e Práticas Relativas às Necessidades Bāsicas ........................... 42

5.3. A Representação das Condições de Existência e das Relações com a Cidade ...................... 54

5.4. Representações e Prāticas de Vestuārio .............. 62

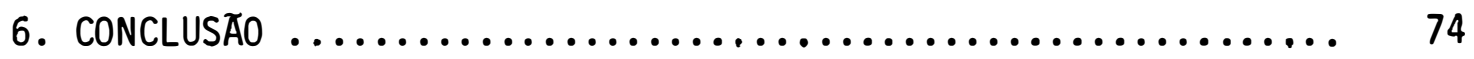

7. REFERENCIAS BIBLIOGRAFICAS $\ldots \ldots \ldots \ldots \ldots \ldots \ldots \ldots \ldots \ldots \ldots \ldots \ldots \ldots \ldots \ldots$

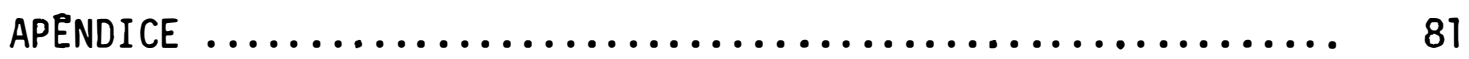


REPRESENTAÇOES E PRATICAS DE CONSUMO NO MEIO RURAL

Maria Elisa de Paula Eduardo Garavello Orientadora: Maria Ignez Guerra Molina

RE SUMO

Inicialmente inspirado em proposições sociolōgicas sobre relações cidade-campo e condições de existência da população rụral, es te trabalho relata uma pesquisa empírica que demonstra a importância do estudo dos sistemas simbōlicos para a compreensão da coerência entre as prāticas e representações daquela população.

Utilizando o conceito de "habitus" desenvolvido por BOUR DIEU (1972) pretendeu-se mostrar que as representações sociais interferem nas prāticas resultantes das condições materiais de existência da população rural orientando-as e estabelecendo a direção que assumem. Nessa proposta de trabalho encontrava-se implīcita a idéia de que a con juntura econômica, por si sō, não è suficiente para explicar a adoção de determinadas präticas de um grupo social. E necessärio considerar tambēm os motivos formulados ao nĩvel das representações. 
A metodologia utilizada baseou-se na técnica de entrevista gravada, com roteiro bāsico mas não limitante. Foram entrevistadas 74 mães de famīlia, que forneceram informações sobre: as prāticas referentes à obtenção dos bens materiais e simbōlicos necessārios à sobrevivência da unidade familiar e as representações que essas famîlias têm de suas condições de vida e de suas relações com o meio urbano.

Verificou-se que as representações da condição atual de existência dos indivĩduos rurais em seu contato cotidiano com o estilo de vida urbano são assimiladas às representações jā existentes da cultura "rūstica" desse meio, e as prāticas dessa população estão de acordo com as representações resultantes.

As novas präticas de consumo adotadas pelas famīlias rurais evidenciam uma busca de igualdade e integração ao meio social urbano, que é percebido como detentor de prestīgio e poder. 


\section{REPRESENTATION AND CONSUMPTION PRACTICES}

AMONG RURAL PEOPLE

Maria Elisa de Paula Eduardo Garavello Adviser: Maria Ignez Guerra Molina

SUMMARY

This work was inspired on sociological propositions about the relationships between town and country populations, as well as about the living conditions among rural people. Its main merit was to show the usefulness of studying symbolic systems for the comprehension of existing consistency between practices and representations of such people.

Through the "habitus" concept developed by BOURDIEU (1972), it was intended to show that social representations do interfere in practices resulting from material conditions of life. This was observed among rural populations. Those practices are directed by their representations. The research project, from its start, supposed that economic factors are not in themselves enough to explain the adoption of certain practices by any social group. Its motivation, as interpreted at the representation level, should be taken into account. 
The method employed was based on the technique of recorded interview with no limiting pilot instructions. 74 housewifes were interviewed, and gave information about: practices used to obtain material and symbolic goods needed for the family unity subsistence; and the representations they have about their living conditions, as well as about their relationships with urban life.

Results showed that representations rural people have about their living conditions are assimilated to those previously existing in the "rustic" culture. There is consistency between rural people's practices and the resulting representations.

New consumption practices adopted by rural families show they look for beeing similar and integrating to urban people, whom are perceived as prestige and power holders. 


\section{INTRODUÇAOO}

Nos ūltimos anos, os trabalhos sobre a população rura] têm abordado questões relativas à expansão do modo de produção capitalis ta no Brasil e suas consequēncias. Tem sido objeto de interesse a perda, por parte do trabalhador rural, dos meios de produção que the asseguram o sustento e a sua consequente proletarização. Os pesquisadores na ārea de Sociologia Rural tem dado ēnfase às implicações do processo de capitalização no modo de produção agrīcola - em uma perspectiva econômica - ou no processo de adaptação do trabalhador rural a um novo meio quando se vē expulso de seu local de origem - numa perspectiva propriamente social.

Poucos trabalhos oferecem informações sobre o modo de vida da população rural e suas estratēgias de sobrevivēncia, face à nova ordem social engendrada pelo sistema capitalista. Este trabalho contribui para esclarecer esse aspecto.

A anālise das diferenciações na produção e de seus vĩnculos com as condições de existência não è suficiente para se compreender 
o modo pelo qual os indivíduos no meio rural percebem essas condições e a elas reagem, desenvolvendo soluçōes especīficas para sua sobrevivēncia. Na medida em que a produção da população rural está vinçu lada à sua subsistēncia, è necessārio considerar também a dimensão do consumo despendido na satisfação das necessidades desses indivĩduos, que a produção capitalista tende a ampliar continuamente, 0 consumo, refletindo as necessidades e aspirações dos indivĩduos, evidencia suas relações com a estrutura social mais ampla.

Uma vez que os determinantes sōcio-econōmicos geram soTuções especīficas para a obtenção dos bens materiais necessārias à sobrevivēncia, pretende-se demonstrar que tanto as soluções adotadas, como os meios utilizados, são coerentes com a representação que os indivíduos do meio rural têm da ordem social.

A esse respeito $\bar{e}$ importante analisar a relação desses in divĩduos com a sociedade mais ampla em que estão inseridos e em função da qual tēm o seu conjunto de necessidades redefinido.

Neste trabalho selecionou-se inicialmente alguns autores que possibilitassem a caracterização das famĩlias de pequenos produtores rurais, sob o ponto de vista da organização de produção e relações com o meio, evidenciando as suas condições materiais de existência.

A forma de provisão dos bens e serviços para a satisfação das necessidades das famīlias varia de acordo com a estrutura mais ampla em que elas estão inseridas, assim como em função dessa mesma estrutura variam as suas necessidades, Desse modo, tentou-se caracterizar a 
relação cidade-campo e as consequências dessa relação para o meio rural, evidenciando a sua adesão a um padrão minnimo de sobrevivēncia, proposto pelo estilo de vida urbano. Para isso, a utilização do conceito de "mînimo vital" mostrou-se adequada.

Partindo da idéia de que as prāticas de consumo das famĩlias rurais não são explicadas apenas em termos econômicos, mas tambēm pelas orientações culturais adotadas, aprofundou-se a anālise a esse nīvel, atravēsdos conceitos de "habitus" e "representação".

As colocações teōricas apresentadas orientaram a anā7ise dos dados empîricos, permitindo a compreensão das relações entre as condições de vida da população rural, as representações que têm dessas condições e as prāticas engendradas por elas.

Acredita-se que este estudo, visando compreender um aspecto da realidade do meio rural ainda pouco explorada, poderā ser ūtil aos profissionais e instituições que atuam nessa ārea. Oferecendo dados sobre o modo de vida da população rural e sua interpretação da ordem social, poderá servir àqueles que consideram que a intervenção nas condições de existência desses indivĩduos não deve basear-se unicamente em conceitos econōmicos e políticos, mas tambēm no estudo de sua cultura e organização social. Especificamente, este trabalho oferece informações ūteis ao economista doméstico, que em seu campo de trabatho visa a melhoria das condições de vida das famīlias. 


\section{CONDIÇÕES MATERIAIS DE EXISTENCIA}

O estudo do modo de vida da população rural na sua relação com o meio ambiente físico, sōcio-econōmico e cultural pode ser efetuado, tomando-se como ponto de referência, a famîlia. Esta é a unidade social mais estreitamente relacionada com a sobrevivência e o bem estar humano, procurando satisfazer as necessidades bāsicas de seus membros, atravēs da reprodução, criação e transformação de produtos, bens e serviços. Além disso, a famīlia tem o papel de fornecer as condições necessārias ao desenvolvimento do potencial humano, prestando serviços não produtivos mas voltados para a realização de fins de interesse social.

Segundo CEBOTAREV (1979), na sociedade latino-americana atual alguns setores privados ou pūblicos têm condições de concretizar com maior eficiência a produção de bens, ou a prestação de alguns serviços como a saūde e a educação. Entretanto, outros bens e serviços não es pecializados como o cuidado de crianças e de velhos, por exemplo, ou de carāter contīnuo e repetitivo como alimentação, higiene pessoal, vestuārio, podem ser realizados mais satisfatoriamente na esfera doméstica, 
particularmente entre famīlias de recursos limitados. Isto é demonstrado pela autora (1979, p.30) que considera este aspecto ainda mais relevante, quando se trata da famīila rural, pois esta "além de participar na transformação de produtos para o consumo familiar, têm a possibilidade de produzir as matērias primas para estes processos". Por esse motivo, considera que a famîlia rural pode reduzir sua dependēncia do mercado e seus gastos com artigos mais necessārios.

Esta generalização não se aplica a todas as famỉlias rurais, porēm a colocação é importante, porque a autora evidencia uma caracterīstica distintiva de um tipo particular de famīlia rural que $\bar{e}$ a de deter os meios para a produção do que the é necessārio. Nesse sentido, ela se torna unidade de produção, além de unidade de consumo, e se diferencia das outras famílias que se organizam como unidades de rendimentos, na medida em que os membros destas vendem individualmente sua força de trabalho, em troca de salārio.

As famîlias rurais desse tipa sobrevivem no Brasil há muito tempo, conforme relata QUEIROZ (1976), coexistindo com as monoculturas de exportação e com as fazendas de gado. Constituem,em seu conjunto,a camada intermediāria na população rural e que sempre existiu no Brasil, mas apenas recentemente foi reconhecida como tal.

Essas famîlias podem em sua forma tradicional, ser identificadas como camponesas, conforme demonstra QUEIROZ (1979, P.T8) quando descreve suas caracterīsticas: "A famīilia constitue sempre a unidade social de trabalho e de exploração da propriedade, sendo que os 
produtos, regra geral, satisfazem às necessidades essenciais da vida; as tarefas do trabalho se dividem entre todos os membros do grupo doméstico, em função das faculdades de cada um, formando assim uma equipe de trabalho. A familia assegura a subsistência de todos os membros; a combinação famîlia-empresa agrícola faz com que se estabeleça uma comunidade de posse e uma comunidade de consumo, a lém da comunidade de trabaTho, sob a autoridade de um membro, que è o pai de família".

Comenta que apesar da aparente uniformidade destes traços, existe uma diferenciação do campesinato, conforme as diversas regiões, e considera que o carăter essencial da definição de camponēs ē "o destino dado ao produto, pois este governa todos os outros elementos com ele correlatos"; este destino é pois, o sustento da prōpria famīlia. Mos tra ainda que o camponês brasileiro sempre teve diferentes formas de relação com a terra: alēm dos proprietārios de extensões variadas de terra, existiam sempre posseiros, parceiros, arrendatärios e os agregados. Afir ma também que este tipo de unidade familiar encontra-se em vias de extinção no Brasil, pois a produção estā tendendo a se organizar sob a for ma capitalista voltada para o lucro e para o mercado.

Mostra existir no Estado de São Paulo inúmeras famīlias de sitiantes que utilizam tēcnicas modernas e que estão voltadas para o comércio, não mais para o auto-consumo, como os camponeses tradicionais. QUEIROZ (1978) identifica o aparecimento dessa categoria de sitiantes com a instalação dos imigrantes alemães e italianos no sul do paîs, e, particularmente no estado, associada às grandes plantações de café. 0 que caracteriza esse novo tipo de sitiantes è a modernização das técnicas 
de produção e o destino dado ao produto, ou seja, a comercialização. Afirma que, apesar dessas transformações ocorridas, o trabalho permanece baseado na unidade familiar.

Apesar do emprego de tēcnicas modernas na agricultura, a autora comenta que essas unidades produtivas têm enfrentado uma série de problemas, sem conseguir resultados satisfatōrios. A divisão das terras, em virtude de heranças que reduzem consideravelmente o tamanho das propriedades, e o solo "cansado" são algumas dessas causas. Alēm disso, o excesso de gasto com insumos e máquinas modernas coloca-os nas mãos dos intermediārios, vendendo as colheitas sem negociar preço, por não terem condições de esperar a alta. Conclui QUEIROZ (1979, p.43)"quan do se examina o problema dos médios e pequenos agricultores mecanizados e modernos, é possīvel indagar se a fraca rentabilidade das empresas não resulta justamente do fato de terem optado pelo modernismo, esquecendo que o lucro é um dos indicadores mais seguros da adaptação a uma sociedade global capitalista".

Desse modo, a autora salienta um aspecto da organização agrīcola desses sitiantes modernos, que parece não corresponder à sua caracterização como empresa, tal como a ela se refere. E o fato de não visar lucro na produção, ou pelo menos, não tê-lo como meta prioritária.

Nesse sentido a unidade agrícola familiar que define seu trabalho em tais moldes, identifica-se com aquela que SILVA (1978) chama de unidade produtiva camponesa. - Sem entrar no mérito da adequação dos conceitos de unidade produtiva camponesa, empresa familiar, sitiantes modernos, ou ainda novos camponeses - o que se pretende neste trabalho é 
evidenciar as caracterīsticas das famīlias rurais aqui referidas na forma como se relacionam com a natureza e a sociedade mais ampla, na sua luta pela sobrevivēncia.

SILVA (1978) analisa as transformações que o desenvolvimento do capitalismo na agricultura brasileira tem imposto às unidades de pequenos produtores familiares. Mostra como estas unidades têm se submetido à produção capitalista e convivido com ela, atē mesmo nos paỉses onde esse sistema produtivo estā mais desenvolvido. Afirma que no Brasil, a pequena produção camponesa é importante tanto pelo fato de constituir a grande maioria das unidades produtivas do meio rural, como por ter um papel marcante na produção agrĩcola e na constituição do pre ço da força de trabalho. Acredita o autor que tal unidade produtiva não è uma forma remanescente de outras épocas, fadada ao extermīnio, mas que faz parte do processo capitalista e é útil ao seu desenvolvimento.

Esclarecendo o que considera como produção camponesa (diferencia-a do sentido clássico $j a \bar{a}$ analisado neste trabalho), 0 autor identifica os elementos que a caracterizam: utilização do trabalho familiar, acesso à terra (em forma de propriedade ou de posse) e aos instrumentos de trabalho, para produzir gēneros agrícolas com o fim de reproduzir a sua unidade que é a famīlia. Explica SILVA (1978, p, 3-9) que"embora a produção se destine em grande parte para o autoconsumo, não se trata unicamente de produção de alimentos; por outro lado, não se tra ta de vender o que sobra do consumo, mas sim de realizar uma produção voltada para o mercado, com a terra, a força de trabalho e os meios de trabaitho que sobram da produção para a subsistência. (...) Não se deve 
confundir a agricultura de subsistência com autoconsumo. Ao mesmo tempo en que envolve um excedente destinado ao mercado ela não implica em completo auto-abastecimento".

Todas estas caracterīsticas permitem unificar uma grande variedade de tipos de pequenos produtores (pequenos proprietārios, parceiros, arrendatārios, posseiros) em uma mesma categoria de anālise, que o autor denomina de camponeses, Outra caracteristica que identifica esse grupo ē a de utilizar a mão de obra de assalariados temporārios durante a colheita, para conseguir a reprodução de sua unidade produtiva.

Em trabalho posterior SILVA $(1980, \mathrm{p} .61-63)$, retoma alguns destes pontos, chamando o pequeno produtor de "novo camponēs" e esclarece que este "pode ter em comum com o 'antigo camponês' apenas a forma, seja porque organiza o trabalho em base familiar, seja porque tem a posse imediata dos meios de produção, ou de pelo menos, parte deles" e a seguir explica: "Na verdade, a 'recriação' desses novos camponeses não ē mais reprodução de produtores mercantis independentes, mas sim a reprodução do prōprio capital. Vale dizer, essa 'recriação' se dā com a crescente perda da 'autonomia anterior do camponês' no prōprio processo de produção que passa a ser agora prescrito - inclusive do ponto de vista tëcnico - pelo capital que o subordina e se the apresenta como uma relação social hegemōnica".

As colocações anteriores justificam a posição assumida no presente trabalho. Assim, considera-se que tendo inicialmente uma caracterīstica de produção para o consumo e venda do excedente, a unidade produtiva familiar, sob as novas condições, tem necessidade crescente 
de especializar sua produção e destinā-1a cada vez mais para o comércio. Dessa maneira, muda a proporção existente entre o volume do que ē produzido para o autoconsumo e o que é comercializável; entretanto, esse fato não interfere na natureza da produção de subsistēncia. o que ē pro duzido para ser comercializado só o é para a obtenção do numerārio, que permita sejam adquiridos bens de consumo. Na verdade, o fim ūitimo do excedente comercializāvel è o sustento da famīlia e não a acumulação do capital. A sua transformação se dā numa tentativa de adaptação às exi gēncias ao sistema capitalista em curso.

Dado pois que essa forma de produção não ē um empreendimento com fins lucrativos, SILVA (1980) afirma que o único fator 1imitante para a exploração camponesa serā o rendimento, monetārio ou não, percebido pela famîlia e necessārio para a manutenção de um "mīnimo vi$\operatorname{ta}{ }^{\prime \prime}$.

A explicitação desse conceito de "mínimo vital", feita de forma brilhante por ANTONIO CĀNDIDO (1964), è de particular interesse neste trabalho e facilita a compreensão do argumento utilizado por SILVA (1978) e que havia sido desenvolvido por MARTINS (1975).

ANTONIO CÂNDIDO (1964, p.11-13) parte da idéia de que existe em toda sociedade a tendência para um equilíbrio entre as suas necessidades e os recursos do meio físico que as satisfaçam. Para que este equilíbrio ocorra, mostra serem necessārios dois ajustamentos, por parte de cada grupo: "1) o encontro de soluções que permitam explorar o meio físico para obter recursos de subsistência; 2) o estabelecimento de 
uma organização social compatĩvel com elas". Acrescenta que hā em cada momento, para cada cultura, "certos minnimos abaixo dos quais não se pode falar em equilïbrio. Mĩnimos vitais de alimentação e abrigo, minnimos sociais de organização para obtē-los e garantir a regularidade das relações humanas. Formulado nestes termos, o equilïbrio depende de uma equação entre o mỉnimo social e o mīnimo vital. (...) Dir-se-ā, então, que um grupo ou camada vive segundo minnimos vitais e sociais, quando se pode, verossimelmente, supor que, com menos recursos de subsistēncia, a vida orgânica não seria possīvel, e com menor organização das relações, não seria viável a vida social: teríamos fome no primeiro caso, anomia no segundo".

Este é o caso da população estudada por aquele autor em um municipio paulista, a respeito da qual observou serem as formas de sociabilidade e de subsistência apoiadas em soluções mînimas, apenas suficientes para sustentar a vida e manter a coesão vicinal.

A esse respeito MARTINS (1975) coloca que as condições de existência do homem rural são moldadas por sua relação econômica com o meio. Entretanto, essa relação assume caracterīstica prōpria na medida em que è baseada no excedente. Sendo assim, o intercâmbio econômico se dā na comercialização do excedente, de modo que as condições materiais de existência da população caipira gozam de certa flexibilidade em relação às crises e irregularidades da sociedade como um todo.

$$
\text { Por outro lado, nota MARTINS (1975, p.107) e neste }
$$
sentido concorda com a posição de SILVA (1978) sobre a produção camponesa, que "o excedente é uma forma de mercadoria que se diferencia das 
outras na medida em que a sua organização $(.$.$) depende das condições de$ mercado e não da organização e da atividade deliberada do produto". $\mathrm{Na}$ medida em que essas condições de mercado são reguladas a partir da produção capitalista dominante (e esta tem possibilidade de conseguir menor custo, pela produção em grande escala, utilização de terras mais férteis, proximidade do mercado) as condições materiais de existência são mantidas ao nĩvel dos minnimos vitajs.

Será preciso, entretanto, discriminar os mînimos aqui referidos nos diferentes momentos histōricos. Quando ANTONIO CĀNDIDO (1964) afirma que a população rural conseguiu um equilībrio entre as relações sociais e o meio a um nîvel mĩnimo, refere-se à sociedade caipira tradicional, que constituia uma vida social de tipo fechado e utilizava técnicas rudimentares. Diz o autor que num estāgio mais primitivo da famīlia caipira, não havia quase negōcios: cada uma consumia o seu produto e nos anos fartos sobravam mantimentos que não eram vendidos. In clusive os tecidos com que se confeccionavam roupas, tinham produção caseira. Também os utensîlios eram na maior parte feitos em casa, e a habitação era extremamente simples. Aspecto significativo apreendido pelo autor é que em consequência desses padrões mĩnimos de vida e da falta de condições estimuladoras, verificava-se pouca disposição para o trabalho e longas horas dedicadas ao lazer.

Vários são os estudos que comprovam esse modo rudimentar de viver das famîlias rurais tradicionais.

NOGUEIRA (1962) cita que as casas eram paupērrimas, onde caixões substituiam cadeiras e mesas, caixas de madeira e arcas faziam 
as vezes de guarda-roupas e onde, ao invēs de louça e vasithame de cozinha, eram usadas antigas panelas de ferro e predominantemente latas vazias de querosene, ōleo ou gasolina; os talheres eram limitadīssimos. Segundo o autor, na maior parte das casas não existiam livros, não se compra vam jornais ou revistas e o relógio era considerado um luxo que poucos se permitiam. Sobre o vestuärio, afirma que era o mais simples possīvel, com tecidos de algodão dos mais baratos.

Compartilhando a idéia, DURHAN (1973) completa que a quan tidade reduzida de numerārio que cada um possuia era insuficiente para a compra do necessārio, tal como o sal, tecidos, armas e instrumentos de metal. Assim, uma situação de pobreza se afigurava em tudo aquilo que não podia ser produzido com as tēcnicas ao alcance desse meio.

Fazendo referência a esse tipo de vida WILLEMS (1961) apre senta as seguintes caracteristicas: pouco valor atribuỉdo à terra e a seus produtos básicos, abundância relativa desses produtos, escassez relativa de numerārio, salārios insignificantes, poucas possibilidades de vender os produtos da lavoura e criação por preços lucrativos. Em decorrência desses fatores, os elementos de cultura material que não podiam ser produzidos pela prōpria comunidade, permaneciam raros e pouco desenvolvidos. Pelo mesmo motivo, verifica-se o esforço da comunidade em tirar o proveito máximo dos recursos que o meio ambiente oferecia. Con sidera esse aspecto da famīilia rura não apenas sinônimo de uma situação econômica deficiente, mas a configuração de um estilo de vida. Analisando famîlias em melhores condições financeiras, notou que ainda entre 
elas, as técnicas de construção de habitações mais desenvolvidas, a variedade na alimentação, as mobīlias e o vestuārio tinham baixa cotação na sua escala de valores.

Interessada em problema semelhante QUEIROZ (1973) mostra a necessidade de descobrir se a fraqueza de consumo que constatou em bairros rurais paulistas ē "decorrente de uma fraqueza econômica, ou se è decorrente de necessidades definidas segundo padrões tradicionais"(Por padrões tradicionais rurais, a autora entende padrões de civilização cai pira que moldam as necessidades de consumo).

0 minnimo vital ao qual MARTINS (1975) se refere entretanto, diz respeito à fraqueza econōmica (nos termos de QUEIROZ) provocada pelo processo de capitalização do campo. Considerando que esse processo tem provocado, entre outras coisas, intensificação nos contatos entre os meios rural e urbano, as necessidades das famîlias rurais passam a ser definidas com base nos padrões urbanos, onde a cultura è muito mais complexa. A natureza dos mīnimos muda então por completo: o nỉvel mīnimo é superado, os graus de auto-suficiēncia social e econōmica se modificam.

Mais uma vez è ANTONIO CÂNDIDO (1964) quem fornece explicações claras a esse respeito. Analisando a expansão da economia capitalista em São Paulo, evidencia a crise que esta provoca nas formas de organização e nas concepções do mundo da famīlia rural. Impelida a comprar os bens que antes produzia, a famīlia passa a ter que vender cada vez mais. Para haver um equilībrio seria necessārio que receita e despesa se igualassem. Contudo são inúmeros os problemas enfrentados na 
comercialização dos produtos agrīcolas. ANTONIO CÂNDIDO (1964, p.130) argumenta que "a formação de preços para os produtos agrĩcolas produzidos em pequena escala obedece a fatores diferentes e muito mais variáveis (na presente conjuntura) do que aqueles mais constantes que regem a formação de preços dos produtos industriais".

Os fatores que influem nas condições de mercado dos produtos são as variações climáticas (seca, chuva excessiva, geada, etc.),a presença dos intermediários que reduzem o preço de compra para obterem lucro na venda, falta de condições de estocagem, o que força o produtor a vender sua produção em qualquer tempo, sem condições de negociar preço.

Entre as adaptações feitas pelas famîlias para enfrentar o desequilïbrio, ANTONIO CÂNDIDO (1964) cita a elaboração de um esboço de orçamento que permita a previsão de receitas e despesas, e uma profun dạ alteração no rîtmo de trabalho.

A esse respeito, SILVA (1978) afirma que para manter as condições de produção, o pequeno produtor muitas vezes tem que recorrer a um baixo consumo e ao mesmo tempo aumentar a jornada de trabalho, além de usar a mão de obra gratuita de sua famîlia e atē das crianças.

Uma possĩvel consequência dessa situação é que, se as muTheres se veem impelidas a se ocupar mais tempo na agricultura, 0 que resta da pequena indústria e manipulação doméstica fica prejudicado, levando ã necessidade de comprar o que antes era produzido. Como exemplo, ANTONIO CANDIDO (1964, p.143) cita o arroz, que, sendo anteriormente 
descascado no pilão, passa a ser beneficiado nas māquinas instaladas na vila. 0 autor faz referēncia a um aspecto extremamente importante, o psĩquico, notando que se a muther "vē a possibilidade de escapar ao esforço penoso de pilar arroz, começa a achar insuportāvel esta tarefa e a se sentir diminuída quando a executa, enquanto nas formas retrógradas de vida caipira, este e outros esforços ma is duros são aceitos sem discussão, visto como não hā alternativas".

Chamando a atenção para o fato de o caipira se desapegar das técnicas antigas, desprezando-as para adotar as novas, o autor afirma que isto se dā não somente pela mudança no rítmo de trabalho, mas por causa do excesso de valorização do traço novo adotado. Conclui que o caipira tende sempre a aceitar um traço novo, quando este $\bar{e}$ proveniente do meio urbano, porque a adoção é elemento de prestīgio para ele.

Esta colocação permite destacar dois pontos relevantes pa ra o presente estudo e que merecem ser desenvolvidos. 0 primeiro deles é a idéia da dimensão simbōlica do comportamento social, aqui esboçada na forma de prestīgio. Este problema serā retomado oportunamente. 0 segundo, estreitamente ligado ao anterior, ē o referente à razão pela qual a cidade è detentora de prestīgio, e por isso influencia os hābitos culturais da população rural. 


\section{SUBORDINAÇAOO E SIGNIFICADO}

\subsection{Relações cidade-campo}

A questão das relações entre meio rural e urbano, e do prestigio deste entre os habitantes daquele, tem sido abordada em diferentes linhas de pesquisa.

Segundo QUEIROZ (1973), do ponto de vista sociológico, o campesinato constitui sempre uma camada subordinada econômica, política ou socialmente, dentro de uma sociedade global, mesmo tendo dominio sobre seus meios de produção. A camada superior pode constituir-se tanto de proprietārios e empresārios rurais de maior posse, como de camadas ur banas, às quais o campesinato sempre está em situação de inferioridade quanto ao prestígio e ao poder.

A diferenciação do rural com o urbano no Brasil, segundo a autora, data do século XIX, quando houve a difusão cultural de um gènero de vida burguês citadino e não propriamente uma urbanização, pois esta estaria ligada à industrialização que veio bem mais tarde. Para 
QUEIROZ (1978, p.57) esse gênero de vida "diferencia a população urbana não apenas segundo nĩveis econōmicos, porēm muito mais culturalmente, sen do que as camadas superiores adotam como sinal distintivo o requinte e um arremedo de cultura intelectual. 0 que è mais, a partir deste momento, julgamos, vida na cidade e vida no campo tambēm passam a diferenciar-se muito em qualquer nīvel social". Entretanto a autora indica que isto se dā em regiões economicamente fortes, pois nas mais pobres, a vida nas cidades é semelhante à do campo. Assim, nesse perīodo a diferenciação entre as cidades estaria ligada à riqueza do meio rural e não à industrialização, no Brasil.

A partir desse momento, as cidades burguesas passam a ser o centro de um consumo diversificado e suas funções se ampliam, desenvol ve-se o comércio e os serviços à população, distanciando cada vez mais meio rural e urbano. Decorre daĩ uma projeção da cidade como pertencen do a um nivel superior ao do campo, em virtude da difusão do gēnero de vida influenciado pela civilização européia. QUEIROZ (1978, p.64) sa lienta que as relações rural-urbano a partir dessa época tornam-se complexas, mas sempre "marcadas por caracteres urbanos, is to $\bar{e}$, em que a ci dade tende cada vez mais a dominar o campo, reduzido a uma posição não apenas de subordinação como tambēm de inferioridade".

Posteriormente, a expansão da industrialização brasileira desenvolve nas camadas superiores entre os produtores e empresārios, o gosto pelo consumo ostentatório, sedimentando ainda mais o gênero de vida aburguesado, diferenciado substancialmente do rústico, predominante entre os habitantes rurais. Por outro lado, a autora nota que na medida 
em que, na sociedade industrializada, os centros urbanos passam a gerar a riqueza, atraindo grandes concentrações da população disposta a exercer atividades diversas, não agrārias, para desfrutar da civilização, o campo perde sua primazia na produção de riquezas. Ocorre novo impulso à urbanização, intensificando a dicotomị campo-cidade jā existente. Para QUEIROZ (1973, p.283) a estrutura de dominação instalada entre ambos, do ponto de vista econōmico, se teria estendido aos valores, aos comportamentos, às estruturas sociais e politicas; inconfundíveis e antinōmicas se mostrariam as relações entre campo e cidade $(. .$.$) .$

Uma constatação interessante verificada por QUEIROZ (1978, p.305) numa anālise entre os processos que envolvem as relações campo-ci dade é que ao nỉvel econômico, tais processos não seguem os mesmos rumos que ao nīvel cultural: "embora suas relações se apresentem muito estreitas (...) a determinação da superestrutura pela infra-estrutura não vai ao ponto das variações da infra-estrutura comandarem todos os processos em curso no interior da superestrutura". Assim, fatores culturais exteriores à sociedade brasileira introduziram mudanças na sua superestrutura como as causadas pelos häbitos culturais burgueses europeus, ainda que não tivessem ocorrido transformações nas suas relações de produção. Segundo a autora essa importação de elementos culturais è possĩvel porque estes se exprimem sempre sob a forma de bens e mercadorias industriais, como a moda vestimentar, a moda alimentar, etc. Tal observação è muito oportuna porque indica a existēncia de um universo simbōlico que tem uma instāncia prōpria, conforme serā visto adiante. 
MARTINS (1975) refere-se às relações do mundo urbano com o rural, como sendo de exploração de umas classes (rurais) pelas as outras (urbanas). Explica que nas ūltimas dēcadas a industrialização no Brasil e o concomitante crescimento urbano imprimiram profundas mudanças entre tais relações, levando à dominação do rural pelo urbano. A economia urbana passou a ser mais compensadora do ponto de vista do lucro, atraindo um grande contingente de pessoas, redefinindo as funções das ci dades. Segundo MARTINS (1975, p.2) observou-se paralelamente a esse crescimento a "elaboração de uma ideologia urbana, em função dos problemas que o processo suscitava, sublinhadora dos valores concebidos, então, como tīpicos das cidades e a elas inerentes". Forma-se então uma concepção generalizada de descrēdito à sociedade agrāria, que passa a ser interpretada como atrasada e incapaz de desenvolver-se social, cultural e economicamente. Questionam-se os seus valores e normas, atribuindo-The apenas o papel de compradora e consumidora de mercadorias, nada tendo a oferecer $\bar{a}$ sociedade que então se forma. MARTINS (1975, p.8) indica o sentido ideológico dessa concepção unilateral, "com um sentido explícito que pode ser notado tanto na divisão da economia, da sociedade, etc., em rural e urbana, quanto na dependencia que se estabelece da primeira em relação à segunda". Pode-se constatar essa ideologia nas avaliações que órgãos e grupos politicos e muitos pesquisadores fazem das condições sociais, econômicas e culturais do meio rural.

PEREIRA (1976) evidencia que com a ampliação dos contatos entre campo e cidade, o habitante rural tem acesso a novos meios de comunicação e toma conhecimento da existência de bens físicos desenvolvidos 
pela tecnologia e novas formas de serviço. Oferecendo uma grande diferenciação do consumo de bens e serviços, o estilo de vida urbano cria e desenvolve necessidades materiais e não materiais jamais despertadas entre os habitantes do meio rural; a cidade torna-se um grupo de referência positivo para eles. 0 autor salienta que o meio urbano representa um complexo de oportunidade de vida comparativamente superior ao rural, na medida em que propicia maior quantidade de consumo, efetivando um padrão de vida mais elevado.

Anteriormente, PEREIRA (1971) havia desenvolvido essa idéia, utilizando o conceito de "socialização antecipada". Afirma que, embora haja uma adesão ao estilo de vida urbano, não hā na sociedade bră sileira a sua efetivação, em virtude da não incorporação generalizada de todos os seus componentes. Além disso, acrescenta que a limitação dos meios materiais e institucionais contribui para que não haja comportamen tos efetivos que correspondam à valorização desse estilo de vida. Desse modo, este apresenta-se sob a forma de uma"socialização antecipada", mais como padrão de avaliação da situação presente, do que propriamente vivenciada naqueles meios que não propiciam a satisfação das necessidades materiais e não materiais difundidas por aquele estilo.

Os textos revistos deixam clara a existência da subordinação do meio rural ao urbano. Contudo, ainda que mostrem o modo como surgiu, que processos envolve, não forneceu suficiente explicação das rạ zões por que se mantēm. A explicação atravēs da influēncia exercida pe la capitalização dos meios de produção no campo não parece suficiente:por que, como os textos indicam, hā outros fatos na vida social que não se 
explicam inteiramente em termos econômicos. Como mostra OLIVEN (1980, p.79) "não é possível postular uma relação linear entre posição sōcioeconômicà e adesão a orientações culturais (...) é preciso ter em conta que não se pode reduzir mecānicamente comportamentos e valores a interesses econōmicos, $j \bar{a}$ que enquanto estes possuem uma conotação eminentemente prática e objetiva, aqueles envolvem dimensões muito mais pessoais e subjetivas". Dimensões pessoais podem estar em jogo, por exemplo, quando agentes sociais rejeitam a proposição de determinados padrões culturais, como constatou ANTONIO CÃNDIDO (1964).

Assim, ē oportuna a colocação de QUEIROZ (1978) quando afirma que, se ao nivel das estruturas mais gerais, como as econômicas, pode-se visualizar claramente os processos dialéticos em que campo e cidade estão envolvidos, ao nīvel de estruturas mais particularizadas, como a cultural, isto jā ē mais difícil. Atribui tal dificuldade tanto à maior complexidade deste nível, como ao fato de existir menos pesquisas nessa ārea, que sirvam de base para anālise. Sustenta a autora que o nūmero de trabalhos sociológicos focalizando fatores econōmicos ē muito maior do que os ligados a fatores sócio-culturais e talvez decorra da a maior complexidade supostamente existente.

Constata-se pois a necessidade de se aprofundar mais a anālise a esse nīvel. Admitindo-se a idéia da autora de que as transformações culturais não advēm necessariamente das mudanças na infra-estrutura da sociedade à qual pertencem, cumpre concentrar a atenção nos processos que ocorrem nessa instância superior, para tentar obter uma 
explicação convincente a respeito não sō das razões que envolvem a subordinação de uma camada às outras, mas tambēm e principalmente, a adesão a valores, crenças e prāticas de camadas consideradas superiores.

\subsection{A Dimensão Cultural ou Simbōlica}

0 primeiro passo para uma perspectiva de anālise ao nīvel cultural é o seu reconhecimento como uma instãncia particular.

Parte-se do pressuposto de que na prātica social resultante da interação entre os indivĩduos, estes desenvolvem um conjunto de simbolos e significados que dão sentido e orientam suas ações, acrescentando uma nova dimensão à sua realidade natural e social: a cultural.

Este componente simbōlico da ação humana è um modo de organização da vida social, fundamentado na criação e manipulação de símbolos que no dizer de DURHAN (1981), mais que parte integrante, ē elemento constitutivo da prātica social. Segundo a autora, existem padrões culturais, ou cōdigo simbōlico, que fornecem orientações, parāmetros ou receitas para a realização das prāticas, organizando assim a vida social. Para a compreensão desse processo BOURDIEU (1972) considera neces sārio não apenas o conhecimento da ordem estrutural em que eles adquirem forma e sentido, como fato consumado, mas também das condiçōes que tornam possĩvel a existência dessas normas culturais e que the dão origem. Partindo da idéia de que existe uma relação dialētica entre os indivĩduos e o ambiente social do qual fazem parte, esse autor desenvolveu uma "teoria da prātica" ou de geração das prāticas. Afirma que as estruturas 
constitutivas daquele tipo particular de ambiente, são internalizadas pe los indivĩduos, e atravēs de seu comportamento aquilo que incorporam vol ta a se exteriorizar. E o que denomina dialētica da interiorização da exterioridade e de exteriorização da interioridade. Nesse processo intervēm o "habitus", sistema de disposições durāveis, estruturas estruturadas predispostas a funcionar como estruturas estruturantes. Este $\bar{e}$ inerente aos indivĩduos, e constitui o princīpio de geração e estruturação das prāticas e representações. E "estrutura estruturada" porque for ma representações do mundo social que refletem as condições materiais de existēncia e "estrutura estruturante" porque dā origem a prāticas coe rentes com tais representações. A interpretação que MICELI (In: BORDIEU, 1974, p. XLI) faz dessa colocação auxilia a sua compreensão: "0 'habitus' vem a ser portanto, um princīpio operador que leva a cabo a interação en tre dois sistemas de relação: as estruturas objetivas e as prāticas. 0 'habitus' completa o movimento de interiorização de estruturas exteriores, ao passo que as prāticas dos agentes exteriorizam os sistemas de disposições incorporadas".

As prāticas não são simplesmente produtos de uma situação conjuntura 1; na sua produção interfere toda a experiência dos indivíduos, sua posição presente e passada na estrutura social, que eles trans portam sob a forma de "habitus". Portanto, este é constantemente atualịzado nas práticas, estruturadas segundo seus princīpios, tendendo a sobreviver ao passado e perpetuar-se no futuro:

Existe, pois, uma relação dialētica entre as estruturas objetivas e o "habitus" como sistema de estruturas cognitivas e 
motivacionais que elas produzem e que tendem a reproduz $\bar{i}-1$ as.

BORDIEU (1972, p.180) propõe que o "habitus", "integrando todas as experiēncias passadas, funciona a cada momento como uma matriz de percepções, apreciações e ações e torna possīvel a realização de tarefas infinitamente diferenciadas, graças às transferēncias analōgicas de esquemas que permitem resolver os problemas da mesma forma(...)" $\mathrm{Na}$ formação dessa matriz de percepções, apreciações e ações, 0 processo de socialização desempenha papel primordial, atravēs da primeira inculca ção familiar, do sistema de ensino e posteriormente dos meios de comunicação de massa. As primeiras experiēncias servem de base para as sucessivas reestruturações que sofre 0 "habitus" em vista das novas experiēncias ocorrentes em toda a trajetōria social dos individuos. Para 0 autor, tais sistemas de disposições durāveis são incorporados a partir de um tipo determinado de condições de existência e engendram as aspirações e prāticas compatîveis com essas condições objetivas e de certa forma adaptadas a elas.

Resulta daĩ que a avaliação subjetiva das oportunidades de éxito de uma determinada ação fazem interferir todo um corpo de conhe cimentos que determina as condutas adequadas à situação, Desse modo, 0 autor evidencia a existência de uma concordância estreita entre as probabilidades objetivas dos indivĩduos, e as suas aspirações ou motivações subjetivas, levando-os a desejar apenas aquilo que podem alcançar. Esta é, pois, uma consequência da "dialética da interioridade e da exterioridade". 
Outro aspecto analisado pelo autor è que sendo os indivỉduos produtos das mesmas condições objetivas, são portadores do mesmo "habitus" e, portanto, este deve ser considerado como "habitus de classe", uma vez que se trata de um sistema de disposições comum a todos os produtos das mesmas estruturas. Melhor explicando, pode-se dizer que as prāticas dos membros de um mesmo grupo ou de uma mesma classe* são dotadas de um sentido unitário e sistemático. Este transcende as intenções e projetos individuais, porque são o produto de disposições geradas a partir da interiorização das mesmas estruturas, ou seja, das bases econōmicas de uma determinada formação social.

Considera BORDIEU (1972, p.188) que sendo o "habitus" "um sistema subjetivo mas não individual de estruturas interiorizadas, esquemas de percepção, de concepção e ação que são comuns a todos os membros do mesmo grupo ou da mesma classe, e constituinte da condição de toda objetivação e toda apercepção, fundamenta-se pois, o acordo objetivo das prāticas e a unicidade de visão de mundo sobre o carāter impes soal e a substituição perfeita das prāticas e visões singulares".

Nesse sentido o autor considera o "habitus" como o funda mento mais sōlido da interação dos grupos e das classes.

Por outro lado, na medida em que as prāticas são adaptadas às estruturas, elas tendem a reproduzi-las, reproduzindo as condições de existência material e as relações de classe. Nesse caso, a cultura assume a função ideológica de legitimar uma ordem social arbitrāria que justifica o sistema de dominação vigente.

\footnotetext{
* Na tentativa de preservar a validade da teoria para todos os tipos de sociedade, o autor utiliza sempre os termos "grupos" e "classes" como sinōnimos. Neste trabalho seră adotado também o termo "camada" evitando as conotações específicas que cada um deles isoladamente pode assumir.
} 
BORDIEU (1974) desenvolve uma anālise a esse respeito tomando como ponto de referência o fato de que o desenvolvimento do capitalismo baseia-se numa complexa divisão do trabalho, a que corresponde uma sociedade de classes, cujas posições relativas são condicionadas à forma pela qual o produto do trabalho é repartido de maneira desigual. Ba seia-se também na concepção de que, no āmbito cultural, os símbolos cons tituem sinais que estabelecem o espaço em que se movem os diversos grupos e classes que integram a estrutura social. Dessa forma, 0 autor reconhece na ordem social não apenas uma distribuição e utilização desigual de bens materiais, que corresponde a uma ordem econômica, mas também distinções simbōlicas baseadas em um sistema de relações de produção e consumo de bens simbōlicos. Assim, estabelece uma distinção entre mer cado de bens materiais e mercado de bens simbōlicos, ao nîvel cultural. Esse mercado è de certo modo manipulado pelos grupos dominantes, que dessa forma controlam os significados culturais e a sua relevância social, estabelecendo os meios de legitimação do poder que detêm.

Nessa relação entre grupos, os bens materiais revestem-se, pois, de significados, e são utilizados para legitimar a hierarquia social resultante das condições materiais de existência.

Entretanto, existe uma interpenetração dos indivĩduos de diferentes classes sociais e estes se envolvem em relações simbōlicas com os indivĩduos de grupos que não o seu prōprio. Existe sempre uma tentativa por parte dos indivĩduos, de apreender o significado dos bens possuĩdos pelos indivĩduos pertencentes a classes hierarquicamente superiores, incorporando, na medida do possĩvel, o seu modo de utilização. 
Aqueles bens que simbolizam mais claramente a posição dos indivĩduos na estrutura social, são por isso os mais valorizados.

Assim, as diferenças econômicas são reforçadas pelas distinções simbōlicas atravēs do consumo de bens que se transformam em signos. Segundo BORDIEU (1974) entre todos os tipos de bens de consumo, são as roupas e os enfeites (mais que um automōvel, a decoração de um apartamento, etc.) que melhor desempenham a função de diferenciação dos grupos, por serem de maior rendimento simbōlico.

Aspecto importante ressaltado pelo autor è o de que na procura da distinção, a busca de um refinamento ē inevitäver, sendo que este é monopōlio de pessoas privilegiadas em uma sociedade. Completando, BORDIEU (1974, p.23) afirma que "ē preciso englobar na simbōlica da posição de classe não apenas os procedimentos expressivos, isto $\bar{e}, \quad$ os atos específicos e intencionalmente destinados a exprimir a posição social, mas também o conjunto dos atos sociais que, independentemente do nosso querer ou saber, traduzem ou revelam aos ol hos dos outros e, sobretudo dos estranhos ao grupo, uma certa posição na sociedade (...)."

Na medida em que os indivĩduos orientam suas prāticas nes se sentido, em virtude da representação social que reproduz a estrutura das relações sōcio-econōmicas, estão legitimando a ordem social vigente e contribuindo para a preservação do "status quo".

Considerando a escassez de estudos referentes às relações entre classes e cultura em sociedades latino-americanas OLIVEN (1980) propõe a anālise de como a dominação de uma ē refletida e mediada pela 
outra. Mostra para isso a relevāncia de se estudar as prāticas e orientações culturais de diferentes classes sociais, em seus diferentes modos de enfrentar situações da vida cotidiana. Tal estudo deve envolver, segundo 0 autor, dois aspectos culturais que não abrangem todo o conjunto de atividades relacionadas à noção de cultura, mas fornecem elementos suficientes para verificar de que modo as desigualdades sociais são interpretadas por diferentes classes de uma determinada sociedade. São eles o estudo de prāticas sociais (padrões de comportamento e estratēgias de sobrevivência compatîveis com a estrutura social) genericamente chamadas de modo de vida, e o estudo dos sistemas de significados ou modos de interpretar e representar a ordem social, formando uma concepção de vida. Estes podem ser referidos como representações sociais.

Esta forma de operacionalizar os conceitos teóricos aqui desenvolvidos $\bar{e}$ extremamente útil para os objetivos do presente trabalho e ao lado das colocações teōricas apresentadas definiram os questionamentos levantados, orientando a anālise dos dados empīricos. 
4. METODOLOGIA

\subsection{Objetivos}

Este trabalho pretende analisar como as relações campo-ci dade interferem nas präticas, tomando-se a camada formada por famīilias de pequenos produtores rurais como subordinada, e a urbana como dominante, conforme as proposições teōricas formuladas anteriormente.

Entre as consequências da intensificação das relações entre meio urbano e rural, verifica-se uma orientação das famīlias no sentido de desenvolver estratēgias específicas para a obtenção dos meios materiais que consideram necessārios à sobrevivência. Pretende-se demonstrar que tais prāticas são coerentes com a representação que os indi vĩduos do meio rural têm da ordem social vigente. Na medida em que as prāticas, especificamente as de consumo, são realizadas para satisfação das necessidades, refletem estas necessidades e as representações da rea 1idade objetiva que Thes deram origem.

Utilizando o conceito de "habitus" desenvolvido por BOURDIEU (1972) visa-se mostrar que as representações sociais interferem nas 
prāticas resuiltantes das condições materiais de existência dos indivĩduos rurais, orientando-as e estabelecendo a direção que assumem.

Nessa proposta de trabalho encontra-se implícita a idēia de que a conjuntura econômica, por si sō, não è suficiente para explicar a adoção de determinadas prāticas por um grupo social. E necessārio con siderar tambēm, os motivos formulados ao nĩvel das representações.

Privilegiar o campo simbōlico numa anālise deste tipo não significa reduzir a importância da esfera econômica no processo de formação da conduta mas, no dizer de BORDIEU (1974, p.25) "significa optar por acentuar explicitamente (...) um perfil da realidade social que muitas vezes passa despercebido, ou então, quando percebido quase nunca apa rece enquanto tal".

Portanto, são objetivos do presente trabalho:

- Analisar a adoção de determinadas prāticas referentes à obtenção de bens materiais e simbōlicos, relacionados às necessidades básicas de um grupo de famīlias do meio rural.

- Identificar as representações que essas famīlias têm de suas condições de vida e de suas relações com a cidade.

- Analisar a coerência entre as prāticas e representações dessa camada da população rural.

- Evidenciar, atravēs dos aspectos observados, os mecanismos de dominação imanentes à relação cidade-campo. 
Tendo em vista a realização dos objetivos deste estudo, a pesquisa empîrica foi planejada visando propiciar dados que fornecessem informações sobre o modo de vida da população rural. Não era intenção fazer uma anālise exaustiva desse tema, mas estudar os aspectos do modo de vida relacionados com a obtenção, pela famîlia, de recursos necessārios à satisfação das necessidades bāsicas.

Assim, os dados deveriam abranger, em princīpio, 0 conjunto de atividades e organização de tarefas destinadas a transformar re cursos em produtos e serviços para satisfazer as necessidades bāsicas dos membros da famîlia. Foram consideradas bāsicas as necessidades de alimentação, habitação e vestuário. Decidiu-se estudar mais detalhadamente o vestuārio, pois incorporando grande significado simbōlico ē extremamente útil como indicador dos fenômenos que se pretendia analisar.

Fazendo considerações a respeito de necessidades culturais, CHOMBART DE LAUWE (1970, p.33) coloca que para determinā-las, "ē importante que se observe o comportamento da população, que se compreenda como os diferentes meios sociais representam a cultura, quais são as suas aspirações fundamentais, qual a consciēncia que têm de suas prōprias necessidades no dominnio cultural". Nesse sentido, era preciso que se obtivesse támbēm, dados a respeito das aspirações das famīlias de pequenos produtores rurais e da forma como representam suas aspirações, suas necessidades, suas condições de vida. Alēm disso, dados sobre a relação com a cidade e 0 que ela representa para essa população, tambēm se mostraram importantes no contexto da presente pesquisa. 
Considerando-se a natureza do objeto de estudo escolhido, optou-se por uma anālise qualitativa. Este tipo de anālise pareceu ser - mais adequado, na medida em que se pretendia verificar o modo como se apresenta a realidade social. Não se pretendia medir a frequência dos fenōmenos internos dessa realidade, e por isso, afastou-se a perspectiva de uma anālise quantitativa.

Levando-se em consideração a afirmativa de QUEIROZ (1978, p.311) de que "a explicação sociológica não ē encontrada nem na qualidade, nem na quantidade dos fenômenos; ē encontrada na sua gēnese", fezz se necessāria a anāitise não apenas das práticas como fatos consumados, mas a adoção de pressupostos teōricos que explicassem as condições que as tornam possiveis e as originam. Diante disso, tornou-se fundamental a discussão dos dados desta pesquisa nos termos propostos por BOURDIEU (1972) e analisados no capítulo anterior.

Para selecionar um grupo de famīlias de pequenos produtores rurais que fornecessem as informações desejadas, optou-se por uma população residente em um municīpio onde o processo de capitalização no campo vem se desenvolvendo em ritmo acelerado. Trata-se do Município de Jaboticabal, SP., cuja economia rural tem sofrido radical transformação frente à instalação de usinas açucareiras em sua região, mas que ainda conserva organizações produtivas para a subsistência.

Dadas as diversas formas de unidades familiares encontradas na referida população decidiu-se considerar famīilia como sendo o grupo doméstico definido por GOLDTHORPPE (1977, p.88), como grupo 
residencial que "consiste em pessoas normalmente relacionadas por descendēncia ou casamento, que vivem num lugar (...) e dividem entre elas as tarefas e a preparação dos alimentos.

Numa tentativa de padronização do tipo de relação que mantêm com a cidade, foram consideradas apenas as famīlias residentes no meio rural. 0 interesse da pesquisa limitou-se a parceiros, arrendatärios e proprietārios que em geral, são encontrados entre os pequenos e mēdios produtores.

\subsection{Definição da Amostra}

Para a definição da amostra, recorreu-se aos vārios ōrgãos institucionais do município - IBGE, INCRA, Casa da Lavoura - que poderiam fornecer dados referentes às unidades familiares e às propriedades rurais.

Os critérios adotados para a realização da pesquisa: a necessidade de ser uma organização produtiva de algum modo voltada para a subsistēncia, a necessidade de posse da terra e dos instrumentos de trabaiho, a definição globalizante de famīlia como grupo doméstico, a obrigatoriedade de residirem no meio rural, reduziam consideravelmente o tamanho da população em foco, mas tornavam impossīvel localizā-la por quem não conhecesse a região.

Tendo acesso ao recadastramento do INCRA, observou-se a sua inadequação para o levantamento das propriedades, por estar desatualizado, segundo o próprio funcionārio local. vārias propriedades 
haviam sido divididas por herdeiros, inūmeras haviam sido vendidas ou arrendadas para as usinas, outras constavam da lista diversas vezes, co mo pertencentes a diferentes proprietārios. Além disso, não havia dados sobre parcerias e arrendamentos ou chäcaras de recreio.

Estas observações foram confirmadas peto engenheiro agrōnomo do Banco do Brasil local, que é natural da região, e, além de trabaThar ali como fiscal da carteira agrīcola hā 32 anos, faz constantes serviços de topografia para a população rural, - e que portanto tem um conhecimento profundo de toda a região. De acordo com as suas informações, soube-se tambēm que o processo de êxodo rural para locais mais distantes, ou para as cidades próximas estava mujto acelerado.

Posteriormente, alguns depoimentos confirmaram este fato, como o seguinte:

"Antes, nestes 4000 metros tinha umas 100 casas, (...) Hoje não tem 10 casas, não tem mais vizinho. A usina passa as moto, derruba as casas, nivela e enterra tudo e planta cana em cima".

Desse modo, não havia possibilidade de uma estimativa numérica das famīlias que se enquadravam nos requisitos exigidos pela pes quisa, e consequentemente a possibilidade de se fazer uma amostragem aleatōiria foi afastada.

Como se pode constatar, vārios fatores influiram para que se optasse por uma amostra seletiva. 
Para a localização das propriedades obteve-se a orientação do engenheiro agrōnomo citado, que forneceu ainda dados para a seleção da amostra nos padrões estipulados. No decorrer das entrevistas, infor mações dos próprios sujeitos auxiliaram a completar o conjunto da amostra, propiciando a localização de novos informantes.

Portanto, não houve um número prē-determinado de entrevistas para a amostra que abrangeu a quase totalidade dos grupos familiares da região. Excluindo-se os raros casos de famīlias não encontradas por ocasião da visita, e 3 casos de pessoas que se recusaram a colaborar, foram realizadas 76 entrevistas, das quais duas foram inutilizadas por falha tēcnica na gravação. Portanto, os resultados descritos dizem respeito a 74 entrevistas de grupos familiares rurais.

\subsection{Coleta de Dados}

Levando-se em conta a natureza do problema e a forma como se pretendia abordā-10, optou-se pela técnica de entrevistas gravadas, com roteiro bāsico mas não limitante. Este roteiro foi elaborado visando obter as informações necessārias. Constou de perguntas gerais pa ra a caracterização das unidades familiares e outras específicas, relativas aos temas propostos. (Apēndice).

A inexistência de estudos anteriores no enfoque deste, nos quais se pudesse basear a elaboração do roteiro da entrevista, reforçou a necessidade de um pré-teste, que foi feito com famīlias da região estudada. 0 resultado foi satisfatōrio, mostrando a necessidade 
de se mudar apenas a ordem de algumas questões, para um melhor encadeamento das respostas obtidas.

Tanto nesta fase como na posterior, a coleta de dados propriamente dita, observou-se que, apōs a apresentação do tema, grande parte dos entrevistados respondia espontaneamente à maioria das questões que constavam do roteiro, o que comprovou a sua eficiência para a obtenção das informações desejadas. Este fato evitou uma interférência excessiva por parte do pesquisador, afastando portanto, 0 inconveniente apontado por QUEIROZ (1981) para esse tipo de técnica. A autora argumenta que a pesquisa com roteiro tem origem nas preocupações do pesquisador, que as impõe ao informante e este tem que se conformar com responder perguntas orientadas por motivações que não são as suas. Evitou-se a rigidez do roteiro, procurando-se obter o máximo de informações espontãneas.

Apesar disso, não se conseguiu evitar a dificuldade que as pessoas tinham de verbalizar sua experiência de vida. Ainda que o tema exposto fizesse parte de seu prōprio cotidiano, percebia-se que para elas era um tipo de questionamento que jamais chegaram a formular. Este problema jā havia sido encontrado por SIGAUD (1971) que, por esse mo tivo considerou a pesquisa como sendo uma "violência relativa"aos indivĩduos.

0 uso do gravador, para registro das informações não constituiu problema. Apōs ser explicado que serviria apenas para não se perder informações ūteis, e para economia de tempo, o informante não opunha restrições a sua utilização. 
Considerando-se que tradicionalmente as prāticas em estu do tem estado, sobretudo, a cargo das mulheres no grupo doméstico, resolveu-se entrevistā-las de preferência. Algumas entrevistas receberam a participação do marido e filhos.

Sendo o objeto de estudo a representação social que os indivĩduos têm de suas condições de vida, o que se procurava apreender era o consenso do grupo a esse respeito, e portanto, o sexo ou papel social dos informantes, não deveria oferecer limitações à pesquisa. Tam bém por esse motivo, as diferenças individuais de idade, local de nasci mento, origem étnica, escolaridade, não foram consideradas relevantes neste trabalho. Da mesma forma, não se julgou necessārio caracterizar, na anālise dos resultados, os entrevistados cujos depoimentos foram citados.

As entrevistas tiveram uma duração de 15 a 50 minutos, conforme a prolixidade das entrevistas (ou de seus maridos) e foram realizadas no período de janeiro a março de 1980 . 
5. ANĀLISE E DISCUSSÃO DOS RESULTADOS

\subsection{Caracterização da População}

Como foi visto no capītulo anterior, o interesse central deste trabalho estava dirigido para grupos familiares residentes na zona rural, dotados de uma organização produtiva voltada de algum modo para a subsistência, e de posse da terra e de instrumentos de trabalho.

Atendendo a tais critérios, verifica-se que a população estudada é constituīda na maioria $(67,6 \%)$ de famīlias nucleares, ocorrendo casos esparsos (6\%) de agregados, como sogra, irmã ou irmão de um dos cōnjuges. Tambēm foram encontradas famīlias extensas $(26,4 \%)$ com três gerações convivendo sob o mesmo teto. 0 número médio de elementos por famĩlia encontrado foi de 5,7 com o nümero mīnimo de 3 e o máximo de 16. A média de idade das mutheres entrevistadas foi de 42 anos.

0 elemento de integração das grandes famīitias ē o casal de velhos que ainda detêm a posse da terra, e consequentemente a fonte dos rendimentos necessārios à sobrevivência. Levando-se em consideração 
que o objetivo do grupo è a sobrevivēncia, a sua constituição estā vinculada às possibilidades de acesso à terra e a insumos, portanto, ao rendimento que 0 trabalho comum pode propiciar.

Todas as famīlias entrevistadas têm acesso à terra para produzir gêneros agrīcolas, com base na mão de obra de seus membros. En tretanto existe uma grande complexidade e multiplicidade de formas de posse da terra. A maioria (72\%) è proprietāria de pelo menos uma gle ba, mas ocorrem casos de arrendamento $(27,9 \%)$ no sistema de terça, parceria ou a conjugação dessas formas na tenēncia da terra.

As āreas ocupadas pelas unidades familiares têm dimensão variada, sendo mais frequentes $(38,2 \%)$ as de 10 a 19 alqueires, nem sem pre contīguas. Tambēm ocorrem com certa frequēncia as propriedades entre 20 e 29 alqueires $(19 \%)$ e de 30 a 39 alqueires (16\%). Hā também algumas menores e outras de maior dimensão, ocupadas pelas famîliasmaio res.

A produção è voltada para o comērcio, predominando a exploração do algodão $(66,2 \%)$, milho $(51,4 \%)$, soja $(29,4 \%)$ amendoim( $23,5 \%)$, $\operatorname{arroz}(25 \%)$ e (em menor quantidade) café $(13,2 \%)$ e cana $(11,7 \%)$. Para 0 consumo doméstico ou para o "gasto" (no dizer das pessoas entrevistadas), são frequentes o plantio de arroz $(60,2 \%)$ e milho $(58,8 \%)$ (normalmente utilizado para as criações de porco e galinha), aparecendo tambēm, com menor frequência o cultivo de feijão $(16,2 \%)$ mandioca(20,5\%), batata $(13,2 \%)$, verduras e hortaliças. 
Algumas familias aumentam sua renda com o aluguel de casas na cidade, o arrendamento de terras mais distantes, e vendendo produtos de criação. Hā 3 casos de homens que trabalham em propriedades vizinhas, algumas horas por dia.

As tēcnicas utilizadas na produção são modernas. Os pequenos produtores utilizam sementes melhoradas e adubo para a plantação. Geralmente possuem um $(41,1 \%)$ ou dois $(30,8 \%)$ tratores, às vezes mais, e implementos agrĩcolas como grade, plantadeira, lançadeira, coThedeira, pulverizados, o que demonstra o nīvel tecnológico de sua produção. Este fato acentua a participação dos pequenos produtores no mer cado, pois a lēm da venda do produto eles têm necessidade de financiamen to para a compra dos insumos.

As unidades produtivas são organizadas com base no trabalho da famīlia, principalmente o dos homens na lavoura. Recorrem à ajuda das mulheres ocasionalmente, em época de safra, por exemplo. A maior parte do tempo, as mulheres dedicam-se ao trabalho doméstico, à criação de pequenos animais e ao cultivo de uma pequena horta. Segundo o depoimento de algumas, o seu trabalho constante nas plantações era necessārio no tempo em que se usava burro e enxadas, mas com a utilização do trator, tornou-se dispensāvel, As crianças tambēm participam de algum serviço, fora do horārio escolar.

Algumas unidades $(22,5 \%)$ contam com um ou dois empregados mensalistas (houve casos, raros, de atē 4). Nos tempos de maior acūmulo de serviço, por ocasião da colheita, todas as unidades empreitam o serviço de diaristas. 
Embora residam na zona rural, essas famīlias estão em contato permanente com a cidade. Excetuando-se as crianças, cuja maio ria frequenta a escola diariamente, em geral os homens vão à cidade duas ou trēs vezes por semana ou mesmo todo dia, para negöcios e serviços de banco; fazem tambēm as compras de alimentos e manutenção da casa. As mulheres vão à cidade, nos fins de semana visitar os familiares, ou a cada quinze dias, um més, fazer compras, normalmente de roupa, cortar cabelo, a médico ou dentista. 0 contato com a vida urbana se dā, além disso, através do rādio e televisão, e menos frequentemente revistas e jornais.

\subsection{As Representações e Prāticas Relativas às Necessidades Bāsicas}

As condições de produção e o meio em que as famīlias vivem, contribuem para que sejam geradas soluções específicas para a obten ção de bens e serviços de que elas necessitam para a sobrevivēncia. A vinculação do consumo à produção nessas unidades agrīcolas familiares manifesta-se de forma peculiar. As famīlias não dispõem de uma renda fixa. 0 que sobra da venda do produto depois do pagamento das despesas

com ele, ē utilizado na satisfação das suas necessidades. Estas :tambēm são equacionadas nesses moldes, Os depoimentos a seguir evidenciam este aspecto.

"Na roça a gente vē o dinheiro sō uma vez por ano. Estamos com o jogo na mão: se vender bem, vai sobrar alguma coisinha, se não, pode atē faltar". 
"Precisa a roça fazer um bom ano, a gente vender bem, dá para pagar tudo o que deve e sobra um dinheirinho, assim, jā é o que basta. Se faz um bom ano e dā para pagar as dividas, a gente sabe que não vai faltar nada...".

Na medida em que as condições de mercado tanto para compra dos insumos e máquinas agrīcolas, como para venda dos produtos são reguladas pela produção capitalista dominante, a condição de vida. das famîlias dos pequenos produtores rurais é mantida a níveis mínimos, con forme MARTINS (1975), mencionado no capítulo II. Essa situação è percebida pelos habitantes rurais. Comentārios como:

\footnotetext{
"faz dar"

"para viver dā, para o futuro é que não dā"

"se não economiza passa vergonha"

"para viver dā, se um dia cai doente é que não dā"

"se tem compra, se não tem fica sem"
}

demonstram o grau de restrição econômica em que se encontram, e a utilização da renda apenas para o estritamente essencial do cotidiano. Não vêem possibilidade de fazer qualquer reserva para uma eventualidade, co mo uma doença, a velhice, um extraordinārio.

Consideram que, entre as necessidades bäsicas, a alimentação é a que pode ser melhor satisfeita. Isto é explicāvel,pois por menor que seja a produção para o consumo, a criação de porcos e galinhas, os ovos, algumas frutas, legumes ou verduras garantem uma refeição sadia, com pouco custo. 
Ainda assim, hā alimentos que não são produzidos no 10cal como açūcar, café, sal, farinha, carne de vaca, cebola e, muitas vezes, o feijão e arroz, alēm dos industrializados como laticínios e latarias em geral. Nesses casos a renda torna-se deficiente. Al gum descontentamento se manifesta em comentārios como: "precisa ser regradinha, nada de bom, simples" ou "fome a gente não passa" e "não come de rico". Esta situação è agravada no caso dos arrendatáriós, cujos patrões estipulam no contrato a obrigatoriedade de desenvolver apenas determinada cultura, não permitindo outro cultivo.

"Comer, mais ou menos. Poderia melhorar, oh! quer dizer que o arroz, o feijão, è tudo comprado. Se a gente coîa aqui, então o dinheiro que compra, podia ser para uma carne a mais, ou outra coisa mais, e não pode, tem que dividir".

Com relação ao vestuārio, as famīlias consideram que "es tā bom, dā". Entretanto a sua aquisição é subordinada às outras despesas.

"Roupa, vai na loja e faz aquela comprinha. Eles dão aquela quantia, que vẽ que não faz falta aquele dinheirinho para segurar para uma doença, assim, para comprar uma coisa, domingo uma carne, ele dá aquele tantinho. A gente vai lá e compra aquele tanto. Quando acabou aquele tanto do dinheiro, jā não dá mais".

Vārias entrevistadas consideram limitado o nūmero de peças no seu guarda-roupa. 
"Não è de bastante uso, que a gente vē por aĩ, cada lugar uma roupa".

"Não tem luxo, nē, um pouquinho que é sō para ir num lugar".

Da mesma forma, grande parte das casas não tem todo 0 conforto que gostariam. Nos poucos casos em que não hā eletricidade no local, a falta de conforto é a ela atribuĩda. As deficiências apontadas nas demais habitações são as pequenas dimensões da casa, o teto sem forro, o piso muito trabalhoso, a falta de "arrumação", com mōveis antigos, falta de cortinas, etc,

"Na casa ainda falta muita coisa, a gente arruma, arruma, nunca acaba, precisa sempre alguma coisa, por exemplo, de utilidade doméstica, todos os mōveis da casa, que jā estão um pouco velho, então jā melhorava com tudo".

Como mostra a tabela a seguir, a maioria das casas tem os equipamentos domésticos ma is comuns: fogão a gās, ferro elétrico, geladeira, liquidificador, māquina de costura, rádio e televisão e em menores proporções, mas ainda em número considerāvel, māquina de lavar e enceradeira. Algumas possuem tambēm toca disco e batedeira de bolo.

E comum a depreciação de alguns dos equipamentos citados, por serem antigos, pequenos ou 47 trapassados, evidenciando-se a comparação com produtos novos lançados constantemente pelas indūstrias e difundidos pelos meios de comunicação. 
Tabela 1. Equipamentos Domésticos Possuîdos pelas Famĩlias Rurais

\begin{tabular}{lcc}
\hline Item & $\begin{array}{c}\text { Total de } \\
\text { famîlias }\end{array}$ & $\begin{array}{c}\% \text { sobre o } \\
74\end{array}$ \\
\hline Fogão a gās & 63 & 85,7 \\
Ferro Elētrico & 62 & 83,8 \\
Geladeira & 59 & 79,7 \\
Liquidificador & 59 & 79,7 \\
Batedeira de bolo & 17 & 22,9 \\
Enceradeira & 33 & 44,6 \\
Rádio & 54 & 72,9 \\
Televisão & 54 & 72,9 \\
Māquina de costura & 64 & 86,5 \\
Māquina de lavar* & 42 & 56,7 \\
Toca-disco & 15 & 20,2 \\
\hline
\end{tabular}

*Entre estas foram incluĩdas as semi-automáticas

Encontra-se alguma diferença entre os resultados aqui analisados e aqueles apresentados por MACEDO (1979) sobre famîlias de operārios de uma fábrica da grande São Paulo e por RODRIGUES (1974) sobre familias assalariadas da mesma cidade.

Deve-se notar que esses dados se referem a habitantes do meio urbano e são, em sua maioria, relativos à população operāria, cujo modo de vida apresenta diferenças marcantes daquele dos habitantes rurais. ATēm disso são anteriores aos atuais. Entretanto o período 
transcorrido entre esses levantamentos e o do presente trabalho, por ser de apenas 6 anos, não deve ter sido suficiente para registrar grandes alterações nós hābitos de consumo, permitindo algumas obseryações interessantes.

Do conjunto de equipamentos estudados por esses autores, alguns têm particular importância para o presente trabalho. A geladeira é encontrada em porcentagem acentuadamente maior entre essas famīlias do meio rural ( $79,7 \%$, contra $54,6 \%$ e $59 \%$ no meio urbano), a máquina de costura (possuĩda por $86,5 \%$ das fami7ias rurais contra $67,4 \%$ e $77,9 \%$ ) e a māquina de lavar, (cuja porcentagem é de $56,7 \%$ em comparação com as da cidade, de $11,4 \%$ e $17,4 \%)$.

Esses dados tornam-se muito significativos quando se con sidera que para os demais equipamentos a porcentagem é menor, nessa população, do que nas pesquisas citadas. Isto vem demonstrar que as diferenças de consumo entre os grupos analisados não se devem apenas a di ferenças de renda, mas evidenciam a interferência das condições do meio sobre o equacionamento das necessidades básicas das famîlias.

0 grande nümero de māquinas de lavar nos grupos de famílias rurais pode ser atribuīdo às caracterīsticas do trabalho com a ter ra, responsāvel pela sujeira das roupas e dificuldade na sua lavagem, e o grande número de geladeiras, à distāncia entre as residēncias e as fontes de alimentos perecīveis. Embora o contato com a cidade seja fre quente, não se pode comparar a facilidade de obtenção de alimentos no meio urbano, pelo acesso a um mercado, supermercado ou açougue num 
momento de necessidade, com os problemas das donas de casa rurais que condicionam a sua compra às idas à cidade.

"Lá tem as coisas tudo facinho. Se quiser uma carne não precisa tirar o dia e ir buscar, se quiser alguma coisa diferente(...)".

Além disso as geladeiras podem ter sido adquiridas em èpocas em que o contato com a cidade não era tão frequente. Quanto às māquinas de costura, podem evidenciar que, se hoje a prātica de confecção em casa não é muito utilizada, houve perīodos em que era a prin cipal forma de obtenção das peças de vestuārio nesse meio.

Verifica-se pois, que as necessidades geradas pelas condições de vida especîficas do meio rural requerem soluções de consumo diversas daquelas do meio urbano.

Segundo as representações que têm de sua existēncia, as famīlias rurais vivem ao nỉvel dos mỉnimos vitais. Isto não significa que vivem de forma rudimentar, mas apenas com o que consideram essencial à sua sobrevivência. Afirmam que poderiam ter uma vida melhor, se tivessem condições mais satisfatōrias para a produção, e, consequentemente, maior oportunidade de consumo, "comendo melhor, vestindo melhor e tendo mais conforto". Outras, mais exigentes, acham que sō poderiam obter uma melhoria na vida se os membros da famîlia mudassem de ocupação, se os filhos prosseguissem nos estudos, se fossem para a cidade,ou, nos casos de arrendatārios, se tivessem acesso à propriedade da terra. 
Grande parte das famīlias afirma que è preciso muito con trole sobre as despesas, caso conträrio podem ter dificuldades em deter minadas ēpocas do ano.

"Tem pro gasto, mas $\bar{e}$ um caso muito dificil, precisa saber controlar muito bem para dar, para passar o ano inteiro".

"Tem hora que passa apertado, outubro, novembro, dezembro, ou quando compra um maquinārio".

Entretanto, è importante observar, que apesar do rigor que sentem ser necessārio em termos de gastos, afirmam que o ganho dá para as necessidades e que vivem "bem"*.

"Tem que dar graças a Deus de manter o que tem porque com a situação que tā na roça è o melhor que podia ser".

"Tá bom, rico a gente não vai ficar mesmo".

"A gente não è assim, que gaste em luxo, então dā".

"0 dinheiro que faz, nunca faz que chega, mas dā".

Este fato pode ser explicado através da proposição de BOURDIEU (1972) de que o "habitus" incorpora as condições de existēncia, determinando aspirações compatĩveis com essas condições, de tal modo que os indivíduos passam a desejar apenas o que percebem como passīvel de alcançar. 0 seguinte depoimento ilustra esse fenōmeno:

Embora seja relativo o que se entende por "viver bem", o termo foi utilizado no trabalho apenas para constatar a satisfação ou não com o tipo de vida. 
"Hoje em dia tá muito difícil, mas gostaria de uma coisa... Se o adubo não fosse tão caro, semente de plantar não fosse tão caro e depois, no fim da colheita sobrar um pouquinho para a gente comprar uma outra coisa, uma casinha na cidade, porém... Gostaria de bastante coisa, mas a gente não adianta nem motivar, porque não adianta, não dā mesmo para comprar".

E nesse sentido que BOURDIEU (1972, p.177) coloca: "(..) os eventos mais improvāveis encontram-se excluỉdos, antes dequal quer anālise, tanto por ser impensāveis como pela 'dupla negação', que inclina a fazer da necessidade virtude, isto $\bar{e}$, recusar o recusāvel e amar o inevitāvel".

Essa disposição tambēm parece estar implīcita nas afirmações muito frequentes de que para viver "bem" é suficiente que se tenha saūde ou "paz e harmonia". Por outro lado essas afirmações podem indicar que outros valores estão em jogo para essa população e que 0 conforto material não está bem cotado na sua hierarquia de prioridades para o necessārio à vida. Ou seja, a noção de "viver bem" pode não estar vinculada à posse de bens materiais.

Sendo muitas as limitações da renda cabe às famīilias decidir sobre as alternativas que devem adotar para a obtenção de bens e serviços. Precisam resolver que atividades podem ser desenvolvidas com vantagem no lar, ou adquiridas fora do ambiente doméstico, para prover os serviços relacionados com as necessidades bāsicas. Assim tanto a forma como são tomadas as decisões, como o tipo de decisões que são 
tomadas com respeito ao local de aquisição dos produtos, forma de pagamento, frequência de compra, e o tipo de bem desejado, são de algum modo baseados nas caracterīsticas do modo de produção.

Na medida em que as prāticas de consumo são viabilizadas a partir do que sobra da produção, elas ficam normalmente submetidas ao chefe da famîlia (seja o pai ou o filho mais velho) que controla a produção e as despesas bāsicas. E ele quem decide sobre o que fazer com a renda familiar, e isto é tacitamente aceito pelos outros membros do grupo, pois "ele sabe melhor se precisa comprar alguma coisa para a lavoura".

Outro aspecto nesse processo de decisão é que "não sobra dinheiro quase para decidir" ou "quando recebe jā tem onde colocar".Assim, apenas em determinadas ocasiões, na compra de algo especial para a casa ou para a famîlia, é que as outras pessoas que a compõem participam das decisões.

Em virtude da produção ser anual, a disponibilidade da renda limita-se à época da venda do produto, após a colheita. E nesse período que são saldadas as dỉvidas contraîdas com a produção, e se estipula o montante para as despesas domēsticas. Este é o motivo apresentado pela grande maioria das familias estudadas de utilizar o pagamento à vista, em detrimento do sistema de crediārio em suas compras.

"Aqui na roça a gente tem dinheiro de ano em ano. Se a gente vai comprar à prestação, a gente não sabe se vai dar para pagar todo mês. Então a gente faz um balanço: 
se vē que dá para comprar, nōs compramos, se não vē ... è assim".

A mesma razão é apontada em alguns casos para justificar o fato de não comprarem de mascates que vendem roupas a domicîitio. Esta ē uma prātica que a grande majoria das famîlias não adota, sendo pou $\cos$ os casos dos que compram roupas dessa forma. Tambēm é pouco frequente a prätica de compra de vendedores ambulantes, que fornecem pão e verdura nas propriedades.

0 sistema de renda anual è apontado por algumas famīi ias como o motivo de seleção do estabelecimento onde fazem as despesas da casa. Estas famīlias compram seus mantimentos e materiais de limpeza nos armazéns da cidade que permitem o pagamento apenas uma ou duas vezes por ano.

Os artigos de vestuārio e equipamentos domésticos são adquiridos por elas no perīodo de venda da produção. Nessa época, fazem uma compra grande de tecidos prōprios para a confecção de algumas peças, e vārias unidades de outras peças de roupa pronta, necessārias para toda a familia durante o ano todo.

Entretanto, essa prātica não foi encontrada em todos os casos estudados, apesar do sistema de produção e das condições materiais serem semelhantes. A maioria das unidades familiares faz compras pequenas de vestuārio no correr do ano, do mesmo modo que aderiu à compra em supermercados para as despesas, sendo que estas passaram a ser mais frequentes. Uma, duas ou trēs vezes por semana, quem vai à cidade 
(normalmente o marido), faz as compras necessārias para o dia a dia, 0 sistema de compras mensais não è muito utilizado.

Isto significa o abandono de prāticas "tradicionais", que poderiam ser indicadas como decorrentes da forma de produção e à disponibilidade de renda apenas anual.

Por outro lado, verifica-se que também dentro do àmbito doméstico algumas prāticas permanecem, enquanto outras são abandonadas ou substituĩdas por novas. O pão caseiro foi substituído pelo pão de padaria. 0 sabão em pedaços, feito em casa, ē utilizado juntamente com o comprado, assim como o sabão em pō, necessário à lavagem das roupas na máquina. Outros produtos de limpeza industrializados também são ado tados. Algumas famîlias ainda confeccionam as peças de roupa para o trabalho, com tecidos de algodão. Outras compram a roupa pronta, preferindo os tecidos de poliester.

Como foi visto no capítulo III, para ANTONIO CANDIDO (1964) tais prāticas podem ser atribuĩdas tanto às mudanças do ritmo de trabaTho das mulheres, em decorrência do processo de capitalização no campo, como ao excesso de valorização dos novos traços culturais,provenientes do meio urbano.

Neste estudo, constatou-se que o trabalho da mulher na agricultura sō é utilizado esporadicamente, e portanto, as mudanças não podem ser explicadas a partir das características do modo de produção. Ou seja, o fator econômico não é suficiente para justificar a adoção de algumas prāticas relativas ao equacionamento das necessidades bāsicas. Nos termos daquele autor, tratar-se-ia da valorização dos traços 
novos propostos pela cidade, o que constitui um fator de representação. Confirmam-se assim as idēias propostas inicialmente de que as präticas resultantes das condições de vida são mediadas pelas re presentações que as pessoas têm dessas mesmas condições.

No îtem seguinte serā analisado o problema sob esse aspecto, entendendo-se que essa perspectiva pode oferecer alguma compreen são do motivo pelo qual determinadas prāticas podem ou não ser adotadas.

5.3. A Representação das Condições de Existência e das Relações com a Cidade

Para analisar o problema apresentado, sob a perspectiva cultural, acredita-se ser preciso conhecer não sō a visão que os indivỉduos rurais têm de suas condições de existência, como tambēm das relações que mantēm com a estrutura social mais ampla da qual fazem parte.

Alguns depoimentos evidenciam a representação que tēm da realidade objetiva, o modo como a interpretam e a ela reagem.

"Precisava melhorar mais o custo de vida, o governo dar maior valor aos mantimentos. Tudo o que a gente compra tā cada vez mais caro e eles não dão valor aos mantimen tos. Se tivesse um valor por igual, o que a gente vende e o que a gente compra, mas o que a gente compra está cada vez mais caro e o que vende não tem valor". 
"A renda no sítio não dā, tā sendo muito pequena $(\ldots)$. Precisava melhorar mais. 0 custo de vida tá muito, a la voura tá muito cara. Dependendo do governo, podia dar uma melhora pra gente porque o governo que tem que dar uma melhora para a lavoura, porque tá tudo caro e a ren da se torna pouca".

"Nada estā bom no sītio porque agora o que interessa $\overrightarrow{\mathrm{e}}$ cana. Só pode estar bom para as usinas. Os bancos favo rece usineiro, o governo ajuda os grandes".

Configura-se pois, um descontentamento generalizado com as condições de produção da forma como estão estabelecidas no sistema capitalista, que estā se difundindo no campo, Evidencia-se tambēm a dependēncia em que se colocam em relação ao "governo", percebido como entidade responsāvel pelo bem estar da população rural. Entretanto as circunstāncias não são percebidas como resultantes da organização da estrutura social como um todo. Esta constatação jă havia sido feita por QUEIROZ (1978).

Paralelamente, hā um outro fator dessa estrutura social mais ampla, que deve ser considerado neste trabalho. Trata-se da presença constante do meio urbano junto à população rural, interferindo na interpretação que esta formula de suas condições de vida e propondo-The novas formas de participação na sociedade. Como lembra MACEDO (1979, p.77), "as avaliações das condições de existência são sempre com parativas, seja face à de outras pessoas, seja face à propria, em outros momentos do processo da vida". Neste estudo tomou-se como 
referēncia, a interpretação dos habitantes rurais do modo como vivem, em comparação com os habitantes urbanos.

Referindo-se ao modo de vida urbana, de uma forma geral as entrevistadas consideram-na "melhor" em relação à da roça. São vārios os motivos apresentados: a maior facilidade de obtenção de bens e serviços, menos trabalho, emprego melhor, salārio mensal, horārio, a não dependēncia das variações climāticas, vida mais tranquila, maior possibilidade de descanso e passeio. Um ponto sempre citado pelas muTheres que têm crianças, è a "facilidade para a escola".

"Queria ir para a cidade por causa de escola para as crianças. Aqui eles precisa ficar na chuva esperando condução. Saem de madrugada, depois tem que ficar na ci dade fazendo hora, porque chegam muito cedo".

"Là vive a vida. Aqui passa a vida".

"Não acho nada bom a vida na cidade. E diferente, um lugar muito apertado, não tem espaço, o movimento é muj to, na roça é mais sossegado. Quem mora na cidade tem mais conforto, principalmente na limpeza, aqui è mais sujeira. Si morasse na cidade, a vida seria melhor em algumas coisas, no serviço, o serviço è outro. Na roça o serviço é mais pesado: enxada, cortar".

"A pessoa que mora lā, trabalha de empregado, todo mès recebe, não tā vendo se chove bastante, vai estragar a lavoura. Na cidade tem mais conforto, trabalha com a 
cabeça fresca".

"A vida na cidade não tem tanta ocupação, trabalha metade. Pra quem pode é melhor, agora quem vive de salārio jā ē mais apertado (...) Quem tá no sītio não pode, não tem sābado, não tem domingo, não tem fêrias, não tem nada, isso que eu acho duro a vida do sítio".

As mutheres, particularmente, consideram a vida na cidade muito mais fácil, por causa da limpeza, o que acarreta muito menos serviço*. Alēm disso, mostram que aî as mulheres não precisam cuidar da criação e da horta e portanto, seu serviço é mais leve.

"A vida no sîtio è sempre mais sacrificada, dā bem mais trabalho, tá sempre sujo $(\ldots)$. Na cidade a casa conserva limpa, lā è melhor".

Entretanto, afirmam que hā vantagens de morar no sîtio, pois tem mais fartura, mais espaço, mais liberdade para viver e para trabalhar.

"O que tem no sītio, ē que se vai no barro, vem de barro, se vai na poeira, vem de poeira. Se tivesse jeito de limpar aqui era mais gostoso, é mais sossegado".

* E preciso considerar que a época em que foi realizada a pesquisa pode ter influīdo nas entrevistas, pois era tempo de safra, que coincide com a seca, e implica acúmulo de serviço, tanto para a colheita como na lavagem das roupas usadas no trabalho. 
"0 sîtio é mais tranquilo, mais sossegado. Na cidade é uma vida mais cativa, todo dia não pode perder hora,per der dia, aqui não. Nessa parte, aqui tem um tempo que trabalha apertado e tem um tempo que folga. Aqui nōs somos terceiros, somos donos de nōs, nōs fazemos o que quer no serviço, agora lá é empregado, é mandado".

A grande maioria $(88,2 \%)$ sustenta que quem mora na cidade tem mais conforto, apesar de que vārias das pessoas entrevistadas con dicionam esse conforto à situação financeira das famîlias.

Merece destaque o fato de vārias das entrevistadas que consideraram ter mais conforto a vida da cidade, quando foram questionadas sobre o que mudaria se sua famīlia fosse morar ali, responderam que a vida se tornari.a mais difícil, pois os homens não encontrariam emprego e teriam que continuar trabalhando na roça. A perspectiva de proletarização é considerada inclusive por aquelas que são proprietārias mas que associam a mudança para a cidade às dificuldades com a produção e necessidade de vender suas terras para saldar as dîvidas assumidas.

"(..) tendo uma condição de emprego bom, um emprego bom jā acho que é melhor. Na cidade tem mais conforto, dependendo da condição do dinheiro, não è a cidade que dā conforto. Na cidade tem pedra e casas, ninguém vai viver daquilo. Depende da condição de vida, emprego(...) Se morasse na cidade, depende do que os meninos iam pegar para fazer". 
"Se for 1ā vou sofrer mais. Eu vou ter mais conforto, mas eles vão sofrer mais. Vão ter que tomar o caminhão para vir trabalhar".

"Na cidade ia ser mais difícil, por causa do serviço. Daī eles iam ter que vir pra roça. Em Jaboticabal, não tem serviço nenhum pra fazer, pra eles que è acostumado a trabalhar na roça".

Desse modo constatou-se que se prevalece entre os habitantes rurais uma ideologia que valoriza o modo de vida urbano, como afirma MARTINS (1975), esta não resiste a uma anālise mais racional, consciente, a nivel pessoal, em alguns casos.

E preciso não esquecer que muitas vezes, a população rural identifica-se com o estilo de vida urbano, tomando este como grupo de referência positivo, fenōmeno tão bem analisado por PEREIRA (1971). Cumpre ressaltar a idéia do autor, de que entre as consequências do estreitamento das relações entre campo e cidade, verifica-se um acrēscimo de consumo da população rural, para satisfação das novas necessidades nela desenvolvidas. 0 acréscimo de consumo se dā, em virtude da adesão a um padrão minnimo de sobrevivēncia proposto pelo estilo de vida urbano. 0 "conforto" a que se referem os depoimentos, diz respeito à satisfação desse padrão mînimo, que seria o"mīnimo vital" proposto por ANTONIO CANDIDO (1964).

Mantendo contato com bens materiais e não materiais desenvolvidos pela cidade, através dos meios de comunicação de massa e da 
escolarização, além do contato direto com esse meio, os indivĩduos da zona rural desenvolvem representações que contribuem para estabelecer a direção das prāticas relativas à satisfação de suas aspirações. Este processo é, segundo BOURDIEU (1972), mediado pelo "habitus", que permite a interiorização dessas condições materiais de existência e configura práticas condizentes com elas. E preciso considerar, entretanto, a afirmação do autor de que as prāticas não são produtos apenas da situação conjuntural, mas tambēm das experiências passadas dos indivĩduos, incorporadas atravēs do "habitus". Nesse sentido, pode-se afirmar que as novas representações resultantes da condição atual de existēncia dos individuos rurais, em seu contato cotidiano com o estilo de vida urbano, são assimiladas às representações jā existentes da cultura "rústica" desse meio e as prāticas dessa população estão de acordo com tais representações.

Constata-se esta ocorrēncia, quando se observa por exemplo, que a maioria das famîlias estudadas faz compras em supermercados, ou seja, locais onde, segundo as entrevistadas, uma grande variedade de gêneros alimentîcios e produtos de limpeza pode ser encontrada a preços accessíveis. Estā aĩ implícita, não apenas a valorização desses bens industrializados como a adaptação das necessidades às limitações da renda.

Por outro lado, ao mesmo tempo que se observam prāticas relativas à valorização do modo de vida urbano, encontram-se outras remanescentes da cultura "rūstica", como a fabricação do sabão, e a técni ca de ferver as roupas no processo de 1 impeza. Essa prātica foi apontada 
como um fator importante na seleção da roupa utilizada para o trabalho em alguns casos: as peças devem ser de fibra de algodão para poderem ser fervidas. Constata-se pois, uma adição parcial e gradual de novas prāticas, coexistindo com as mais antigas.

Segundo considera MICELI (1972, p. 176) esta constatação è plenamente justificāvel, jā que no Brasil, "em virtude das insuficiências e do carāter 'disnômico' que qualificam o sistema nacional de produção - distribuição - consumo, determinadas camadas sociais(...) estão submetidas apenas em parte ã imposição do arbitrārio cultural dominante, podendo por esse motivo, assegurar a continuidade da matriz de significação que thes foi incutida pela primeira socialização".

As diferentes combinações de prāticas de uma ou outra cultura podem ser atribuīdas aos vārios graus de submissão ã cultura dominante, decorrente de contatos diversos com ela. Assim, aqueles que foram submetidos a um contato maior, como è o caso dos jovens atravēs da escolarização, apresentam uma carga maior de aspirações e prāticas relativas ao modo de vida urbano, como podem ilustrar os seguintes depoimentos:

"0 moço se veste melhor, ē moço, vê, tem essa ilusão". "Pro rapaz è sempre melhor (...) a rapaziada jā viu, nē, tem uma roupa, aquela lā jā não tā boa, jā quer outra. Tem o dinheiro, vai lā e escolhe da boa vontade deles". 
"Vou ter que comprar todos esses aparelhos domésticos, porque tenho minha filha de 22 anos, sabe nē, moço ē exigente pra essas coisas".

Resta, finalmente, analisar o aspecto simbōlico de que se revestem os bens materiais nas relações das pessoas do meio rural com a estrutura social mais ampla, o que se fará atravēs do estudo das prāticas e representações do vestuário.

\subsection{Representações e Práticas de Vestuārio}

0 vestuärio, sendo o bem material que permite maior rendimento simbōlico, constitui valioso instrumento para a anālise do aspecto simbōlico expresso nos bens materiais.

Os dados mostraram que o vestuārio das famīlias rurais è renovado periodicamente, conforme as necessidades de cada um de seus membros. São poucos os casos remanescentes em que é feita uma compra grande para todos, por ocasião da venda da produção. Aqueles que estão precisando, compram algumas peças mais urgentes, a menos que haja uma ocasião especial, como uma festa ou casamento, quando consideram im portante que todos comprem uma roupa adequada para o evento.

Na seleção do vestuārio, o fator mais considerado por eles è o preço. A qualidade e outros aspectos como modelo, cor, gosto, moda, são algumas vezes levados em conta, mas sempre condicionados ao preço. 
"Escolhe na base de servir o necessitado e de servir o preço que a gente vai pagar. Não vai atrās de modelo, nem de artigo se é melhor, porque o melhor é mais caro $(\ldots)$. E conforme a precisão, povo na roça não vai atrās de uso, sabe, tando vestido, tando limpo"...

"Escolhe pelo preço, mais... A gente tem que fazer um ba lanço pelo preço, porque às vezes gosta de um modelo, de um tecido diferente, mas é caro, não dā..."

"Tudo o que diz mais barato, tudo que é simplinho".

As roupas são diferenciadas conforme a finalidade: as de sair são usadas apenas para esse fim, do mesmo modo que as de trabalho. "Gināsio é gināsio, sair é sair, roça é roça".

"Para casa é outra, de domingo é outra, de sair é outra, tem para variar".

Em muitos casos $(44,1 \%)$ a variação tambēm se dá nas caracterîsticas da roupa utilizada para cada uso. Quando isto acontece, as roupas para o trabalho na roça são confeccionadas em casa, especialmente para essa finalidade, com tecidos resistentes de algodão: brim "ranca-toco" (conforme designação dos prōprios sitiantes) e mescla ou xa drez para as camisas. As mulheres entrevistadas afirmam que, dadas as caracterīsticas do serviço da roça, as roupas necessitam muita lavagem e se tornam muito gastas com o uso. Não sendo confeccionadas com tecidos "fortes", ou "grosseiros", a sua duração é curta, e isto trās problemas, jā que as compras de reposição desses artigos não podem ser constantes. 
"As do trabalho são feitas especialmente. Se eu compro tergal pro meu marido, não dā, estraga porque eu tenho que ferver a roupa. Então eu compro um tecido que eu posso ferver, então aquilo è só para trabalhar. Chega em casa, toma banho jā tem a roupa de tergal, amanhã jā tem a do trabalho, ē assim".

"Roupa de trabalhar ē mais grosseira. Não são sō as de domingo, que põe no serviço. Não dā para aproveitar as velhas, porque quando põe no serviço já tá mais surrada, não atura tanto quanto devia aturar, quando vai pro batente".

"0 que fica mais velho vai pondo em casa. Algumas as$\operatorname{sim}(\ldots)$, eles não usam camisa de manga comprida para sair. Então a gente compra o pano e tem que fazer camisa de manga comprida pro serviço, por causa do sol".

Em outras famīlias, o problema é resolvido de forma diversa. As camisas são compradas feitas, de um tipo popular, com preço acessîvel. A adesão às camisas e calças de poliester foi constatada principalmente para as roupas dos homens mais velhos. Segundo declaram, esta é uma prätica mais vantajosa, para este tipo de tecido, tem preço menor do que o brim, e é mais fácil o seu processo de limpeza, "não necessitando "ferver". Nesses casos, as roupas são usadas inicial mente para sair e quando se tornam ma is velhas, são postas no serviço. Esta prática é muito utilizada por aqueles que não compram em especial para o trabalho, e preferem adquirir algumas peças com mais frequência. 
"Faz um pouco de diferença entre roupa de sajr e usar pa ra o trabalho. E mais ou menos a mesma coisa. Uma roupinha mais ou menos clareando, passa para a roça. Não faz especialmente para o serviço. Porque no tempo de comprar para o serviço, já compra para passeio. Sempre aproveita a mais velha para o serviço".

"Quando fica velha, usa no serviço. Antigamente comprava mescla para trabalhar, mas dava muito trabalho para lavar. A gente compra tergal, lava bem, num instantinho seca, entoa faz isso: a mais velha vai deixando pro serviço e compra nova para passear".

Portanto, tambēm na anālise das prāticas ligadas ao vestuārio, verifica-se a permanēncia de algumas antigas, juntamente com outras mais modernas, ligadas ao estilo de vida urbano, que o sistema capitalista de produção tem propiciado. A opção por peças mais ou menos durāveis, em menor ou maior nūmero, é uma prática que evidencia o grau de adesão ao modo de vida da cidade. Como jā foi considerado anteriormente, a alteração de tais prāticas é proporcional à medida em que os indivî̉uos rurais são expostos às caracterīsticas da vida citadi na e à eficácia do "habitus" da cultura "rūstica" responsāvel pela institucionalização das prāticas. Os depoimentos a seguir evidenciam alterações tanto no modo de obtenção do vestuārio, como no tipo usado,den tro de uma mesma famîlia, e que podem ser indicativos da direção que estão assumindo tais prāticas, face aos apelos da cultura urbana. 
"Roupa, de primeiro a gente fazia compra mais grande. Agora não, a gente compra assim, o que precisa".

"As de sair são mais modernas. As de trabathar jā não precisa muito de luxo. As de sair que vão ficando mais velhas, usa no serviço. Agora faz tempinho que não faz especialmente pro trabalho".

Outra variação encontrada na obtenção das peças de vestuārio diz respeito à forma de confecção. A grande maioria das famīlias $(77,9 \%)$ compra roupas feitas, principalmente aquelas destinadas pa ra sair. Poucas $(1,2 \%)$ são as famīlias que fazem todas as peças necessārias na prōpria casa, ou que têm o costume de mandar fazer as que necessitam $(1,0 \%)$. Não é rigido o sistema de obtenção das peças de vestuārio. Os vārios modos de confecção podem ser utilizados pelas famīlias, em casos especiais, ou conforme o tipo especīfico de roupa que se pretende obter, como por exemplo, o terno de homem, um vestido para uma criança, uma roupa para um casamento, ou mesmo uma camisa de modelo "di ferente".

Parece não haver relação entre as diversas formas de confecção e o sexo e idade dos membros da famīlia, a não ser na roupa dos jovens, que em geral é comprada feita. A opção por comprar feita, fazer em casa ou mandar fazer estā mais ligada à finalidade da peça (se é para o trabalho pode ser feita em casa)e aotipo da peça (calças em ge ral são mandadas fazer ou compradas feitas). A habilidade para costura de alguēm do grupo doméstico ou mesmo o seu tempo disponível também 
influem no modo de confecção mais utilizado.

E interessante notar que apesar de $86 \%$ das famîlias possuirem máquina de costura, em apenas $1,2 \%$ delas as roupas são costuradas em casa (duas costuram para fora). Em $49 \%$ dos casos, as mulheres afirmam ter condição de costurar "sō alguma coisinha". Entre as peças feitas em casa pode-se incluir as roupas para o trabalho, algum vestido "ligeiro" e peças para a casa, como guardanapos, aventais, toalhas, etc. Talvez o pouco conhecimento de corte e costura, contribua para que apenas as roupas para "casa" e para o serviço sejam feitas na unida de doméstica, por não exigirem técnica mais aperfe.içoada: Entretanto, a limitação de tempo das mulheres ē tambēm muito citada como motivo para não se confeccionar roupas em casa. Por outro lado, um fator que não deve ser ignorado é que a facilidade de comprar a roupa feita desestimu la a mulher para a execução desse serviço. Isto è evidente na seguinte afirmação:

"Roupa de todos è variāvel. Se eu tenho de fazer, então eu faço. Talvez compra pronta conforme a necessidade da gente $(. .$.$) eu prefiro mais comprar pronta do que$ ter que comprar, ter que chegar em casa, ter que corm tar, ter que fazer".

De qualquer modo, segundo as entrevistadas as "roupas me Ihores", utilizadas para sair, são compradas feitas, pois "comprado fei ta eles contenta mais", "a roupa pronta cai melhor". Assim, fica evidente a valorização da roupa comprada feita pelas famỉlias rurais 
observadas. A compreensão desse fato parece ter ligação com a relação que mantêm com a cidade.

Como $j \bar{a}$ foi exposto, as famīlias fazem uma diferenciação entre as roupas de sair e de trabalhar sendo que as primeiras são sempre consideradas "melhores". Esta separação, ainda que tenha uma causa econōmica, pois "se for trabaihar com as de sair, o dinheiro não dā", pode ser relacionada à representação que têm, de que para ir à cidade, as pessoas devem estar melhor arrumadas*. São vārias as afirmações que confirmam essa idéia:

"Para a cidade o tecido ē melhor, tudo feito diferente. Lá na cidade não dā para andar com uma roupa meio rasgada, ou serzida ou remendadinha, tem que andar mais..., aqui no sîtio pode andar com um mais velho".

"Pra sair a gente põe a roupa mais boa e pra casa jā $\bar{e}$ mais... no sítio a gente anda de qualquer jeito".

Nota-se que a razão dessa prātica é inteiramente social:

"No sîtio, a gente veste é mais simples, porque não ē povoado. Tem essa facilidade no sītio, a gente não se incomoda de se arrumar muito porque tā sōzinha".

* Melhor para elas significa roupas mais novas, mais adequadas aos padrões citadinos. 
"Aqui, nōs semo daqui, a gente vamos daqui na roça, não encontramos ninguēm. Aqui em casa, quem pode vim dentro da nossa casa, nē, quase nirguēm vem. Então, lā não, sem pre sai, casa com casa, sai na rua, fica chato estar mal arrumada do que aqui, que nunca se torna tão feio". Pode-se assim caracterizar o vestuārio como fato social, utilizado como elemento de comunicação entre os componentes de um grupo ou sociedade. Essa sua caracterīstica ē de algum modo reconhecida pe las entrevistadas:

"E importante vestir "bem" porque a gente vive numa sociedade, aj, e vai viver como perto dos outros!".

"Eu acho que não ē importante vestir bem, agora pros homens do mundo tem importāncia".

Segundo RIVIERE (1977, p.178) o traje, na forma como $\bar{e}$ utilizado na sociedade atual, "possibilita não sō uma comunicação com o meio social no qual se desenvolve, mas tambēm, ao evidenciar toda uma série de circunstāncias sociais e culturais, é portador (...) de toda uma constelação de valores com o mesmo carāter de obrigatoriedade, e que provavelmente permitirão um intercāmbio de informação entre as pessoas e grupos, utilizando a linguagem universal da imagem". Particularmente importante para este trabaiho è a afirmação da autora de que "a existēncia de informação depende da organização dos signos e sinais informativos em um código suscetīvel de ser utilizado e interpretado pelos sujeitos". 
Retomando a idéia de BOURDIEU (1974) pode-se afirmar que esse cōdigo é controlado pelos grupos ou classes dominantes, estabelecendo os meios de legitimar seu poder e prestígio, resultante das condições materiais de existência. Nessas circunstāncias, o vestuārio, es pecificamente, ē utilizado não apenas como meio de comunicação das caracterīsticas dos indivî̉duos, mas também como critério para a sua classificação na estrutura social. A função de diferenciação do vestuārio assume importância pela possibilidade de adotar sucessivamente diferentes signos distintivos.

Entretanto, para institucionalizar a hierarquia dos bens materiais e simbōlicos que legitimam o poder dos grupos dominantes, estes dissimulam a dominação, tornando acessỉvel aos outros grupos, de forma vulgarizada, o conjunto de bens próprios de sua cultura, atravēs do mercado de bens simbólicos (conforme designação de BOURDIEU, 1974). Este mercado orienta-se pelas leis da rentabilidade capitalista, por isso, seus produtos são lançados para conquistar o maior público possîvel. Os mejos de comunicação de massa, e o avanço tecnológico das indústrias, tornam possivel o acesso das camadas populares a bens de maior valor simbōlico, pelo menor custo.

Por outro lado, é preciso considerar que os indivĩduos de grupos ou classe subordinadas, ao se envolver em relações com individuos de grupos superiores da estrutura social, tentam incorporar o significado dos bens possuîdos por eles, bens esses que operam como indicadores de sua condição social. 
Considerando-se, pois, a categoria das familias rurais estudada no presente trabalho como subordinada, e a camada formada pela população urbana como dominante, conforme a orientação teōrica adotada no primeiro capitulo, pode-se afirmar que nas relações que aquelas famīlias estabelecem com o meio urbano, suas prāticas são orientadas para um consumo de bens dotados de rendimento simbólico. Algumas práticas relativas à obtenção de tais bens poderiam então ser interpretadas como um esforço no sentido de buscar uma posição mais integrada no meio social. Este è o caso da compra de confecção pronta que por sua natureza è carregada de conteúdo simbōlico.

Mostra MICELI (1972, p.200) que esse tipo de comportamen to "obedece à lógica da distinção, que torna o sistema de classes um regime de diferenças, polarizado entre o estilo de vida das frações;que compõem a coalizão dominante e a estrutura das necessidades que distingue estilos de vida pré-urbano-industriais" (rurais no caso presente).

E conveniente notar que embora as práticas de consumo revelem o esforço dos grupos subordinados para assemelhar-se aos dominantes, as diferenças objetivas existentes entre esses grupos permanecem.

As pessoas privilegiadas desenvolvem refinamentos que traduzem sua distinção, reforçando suas präticas habituais. Esse refinamento é captado por algumas das mutheres entrevistadas, com percepção mais apurada, ainda que não consigam verbalizar claramente: 
"Aquele da cidade tem mais... Não sei se tem mais tempo de arrumar, eu não fui acostumada com isso. E nas pintura, è mais outros arranjos que a gente aqui no sitio, a gente não..."

"Na cidade vestem diferente, $\bar{e}$ tudo. E mais assentada no corpo, bem feita $(\ldots)$ é tudo. 0 povo da roça caiu na cidade, è conhecido mesmo. E pelo andar, é tudo".

"Na roça parece que a gente compra roupa e faz e não fica que nem os da cidade. Não sei se é porque jā tem o jeito da cidade, eu não sei. Na cidade tem outro modo". "Principalmente o pessoal do sîtio pode por a roupa meThor que tem para ir na cidade. Eu acho que é separado, não sei. E outra limpeza na cidade. Por mais bem arru mada que esteja, não é igual, não. Diferença no modo, elas são ma is que a gente, sei $7 \bar{a}$, não é a roupa, è a pessoa. Quem trabalha é queimado da pele, sempre as unhas sujas, è outra limpeza".

Um aspecto interessante observado e comentado anteriormente, quando se tratou do modo de vida da cidade, é que também com relação ao vestuārio as pessoas consideram não ter condições de mudar, se se transferissem para aquele meio. Afirmam que deixariam de usar as roupas do serviço diārio, mas não poderiam fazer mais despesas com 0 vestuārio, porque a sua situação econômica não melhoraria na cidade. 
"Se morasse na cidade seria do mesmo jeito porque a gente quando vem daquela origem, desde criança, segue naquele ritmo mesmo, eu acho que é".

Confirma-se também nessa afirmação a existência do "habitus", que estrutura as präticas, não sō de acordo com as condições de existência atuais dos indivĩduos, mas tambēm com suas experiências passadas. A influência da cultura dominante tambēm se faz notar:

"Se morasse lā, ia vestir diferente porque a gente vē mais coisa, vê o que tá mais na moda, comprava mais".

Assim, prāticas relativas às duas representações citadas poderão ocorrer conforme o grau de eficiēncia do "habitus" de origem das pessoas, em legitimar sua cultura, ou do grau de exposição delas aos meios de comunicação que transmitem os traços da cultura dominante. 
6. CONCLUSAOO

Neste estudo verificou-se que as necessidades geradas pe las condições de vida especīificas do meio rural requerem soluções de consumo diversas daquelas do meio urbano. As condições de produção das famílias de pequenos produtores rurais, assim como o meio físico em que vivem, interferem no equacionamento das necessidades básicas e nas estratégias que adotam para satisfazè-las.

Entretanto, as condições de mercado da sociedade mais ampla, em que essas famîlias estão inseridas, não permitem que a renda percebida seja suficiente para viverem alén do padrão mînimo de sobrevivência traçado por elas. Uma vez que esse padrão ē estabelecido a partir do estilo de vida proposto pelo meio urbano, gera um acréscimo de consumo de bens industrializados. Assim, constatou-se que o nĩvel mĩnimo considerado inclui esses bens e não se restringe à escassez de consumo encontrado no modo de vida rudimentar de habitantes rurais em épocas anteriores. 
Esta constatação sobre o mỉnimo vital, além de evidenciar a existência de uma subordinação do modo de vida rural ao urbano, confirma o problema teörico em torno desse conceito. Verifica-se a impossibilidade de se estabelecer, "a priori", o mīnimo necessārio à sobrevivência de um grupo, jā que o necessārio é determinado por numerosos fatores que incluem suas condições físicas de existência e as relações que mantêm com a sociedade mais ampla.

A teoria desenvolvida por Pierre Bourdieu revelou-se par ticularmente ūtil para a compreensão dos fenōmenos observados, permitindo concluir que as prāticas resultantes das condições de vida são me diadas pelas representações que as pessoas têm dessas mesmas condições. Tais representações são estruturadas tanto a partir da situação presente das familias rurais em sua relação com o ambiente físico e sócio-cul tural, como também com base nas suas experiências passadas nesse ambien te.

Observa-se, pois, uma assimilação de novos elementos ao "habitus" formado em toda a trajetōria de vida das pessoas, os reflexos dessa assimilação de novas representações ao quadro daquelas jā for madas evidenciam-se no aparecimento simultāneo de prāticas ligadas às culturas "rüstica" e urbana.

Essas reflexões permitem concluir que as novas representações, contendo elementos da cultura rural, terão sempre caracterīsticas prōprias, em parte determinadas pelas condições materiais de existência. 
As prāticas de consumo adotadas pelas famīlias rurais evidenciam uma busca de igualdade e integração ao meio social urbano, que è percebido como detentor de prestîgio e poder.

Embora os habitantes rurais passem a adotar as präticas condizentes com o estilo de vida urbano, não superam as diferenças obje tivas existentes entre os grupos, limitando-se a legitimar a cultura proposta por aquele meio que detêm o poder. Estão pois, contribuindo para, de algum modo, manter a ordem vigente. 
7. REFERENCIAS BIBLIOGRÄFICAS

ANTONIO CĀNDIDO, 1964. Os parceiros do Rio Bonito. Rio de Janeiro, Lí vraria Josē Olympio Editora.

BOURDIEU, P. 1972. Esquisse d'une thēorie de la pratique. Genève, Librairie Droz.

BOURDIEU, P. 1974. A economia das trocas simbölicas. São Paulo, Edito ra Perspectiva S.A.

CEBOTAREV, E. 1979. Mujer rural y desarrollo. Bogotā, Centro Internacional de Investigaciones para el Desarrollo.

CHOMBART DE LAUWE, M.J. 1970. Images de la culture. Paris, Editions Payot.

DURHAN, E.R. 1973. A caminho da cidade, São Paulo, Editora Perspectiva S.A. 
DURHAN, E.R. 1981. Cultura e Ideologịa. Folhetim, Folha de São Pau10, São Paulo 315:6-7.

GOLDTHORPE, J.E. 1977. Sociologia e antropologia social: uma introdução. Rio de Janeiro, Zahar Editores.

MACEDO, C.C. 1979. A reprodução da desigualdade. São Paulo, Editora HUCITEC.

MARTINS, J.S. 1975. Capitalismo e tradicionalismo. São Paulo, Livraria Pioneira Editora.

MICELI, S. 1972. A noite da madrinha. São Paulo, Editora Perspectiva S.A.

NOGUEIRA, 0. 1962. Familia e Comunidade. Rio de Janeiro, Centro Brasileiro de Pesquisas Educacionais.

OLIVEN, R.G. 1980. Urbanização e mudança social no Brasil. Petrōpolis, Editora Vozes Ltda,

PEREIRA, L. 1971. Estudos sobre o Brasil contemporâneó. São Paulo. Livraria Pioneira Editora.

PEREIRA, L. 1976. Urbanização e subdesenyolvimento. In: Pereira, L. org., Urbanização e subdesenvolvimento, Rio de Janeiro, Zahar Editores. 
QUEIROZ, M.I.P. 1973. Bairros rurais paulistas. São Paulo,

Editora

Duas Cidades.

QUEIROZ, M.I.P. 1976. O campesinato brasileiro. Petrópolis, Editora Vozes Ltda.

QUEIROZ, M.I.P. 1978. Cultura, sociedade rural, sociedade urbana no Brasil. Rio de Janeiro, Livros Técnicos e Cientīficos, São Paulo, Editora da Universidade de São Paulo.

QUEIROZ, M.I.P. 1981. Variações sobre o emprego da tēcnica de gravador no registro da informação viva. Cadernos. Centro de Estudos Rurais e Urbanos. São Paulo, 1ํ sērie, nov., 16:107-116.

RODRIGUES, J.A. 1974. Familia assalariada: padrão e custo de vida. São PauTo, DIEESE, no 2.

RIVIERE, M. 1977. La moda, icomunicaciōn o incomunicaciōn? Barcelona, Editorial Gustavo Gili.

SIGAUD, L.M. 1971. A nação dos homens - uma anālise regional de ideologia. Rio de Janeiro, U.F.R.J. (Dissertação de Mestrado).

SILVA, J.F.G. coord. 1978. Estrutura agräria e produção de subsistência na agricultura brasileira. São Paulo, Editora HUCITEC. 
SILVA, J.F.G. 1980. A pequena produção e as transformações da agricultura brasileira. Cadernos do CEAS. Salvador, set/out., 69:56-67.

WILLEMS, E. 1961. Uma vila brasileira. Rio de Janeiro, Difusora Europēia do Livro. 
A PENDICE 
ROTEIRO DA ENTREVISTA

1. Caracterização das Unidades Produtivas Familiares

- Dados sobre o Grupo Familiar: lista das pessoas que moram juntas, parentesco em relação ao chefe, sexo e idade.

- Sistema de posse e tamanho da propriedade.

- Tipo de produção: produção para o mercado e para o consumo.

- Mão de Obra utilizada na produção.

- Outras fontes de renda.

- Tecnologia utilizada: māquinas e implementos, adubo, inseticida.

2. Questões para a orientação da entrevista

- 0 que a senhora acha que é importante para uma famīilia, ou para sua famîlia viver bem?

- Sua famîlia vive bem?

- Acha que sua famīlia poderia melhorar de vida?

- 0 que seria preciso para melhorar de vida?

- Para a senhora, o que ē melhorar de vida?

- A renda da sua famîlia dā para todas as necessidades? 
- Dá para comer como a senhora gostaria? Acha que a comida deveria ser melhor?

- O ganho dā para as roupas necessārias? Gostaria que sua famîi ia se vestisse melhor?

- Na sua casa, a sra. tem todo o conforto que gostaria? o que acha que poderia ser melhor?

- Possui

fogão a gãs

māquina de costura

ferro elētrico

rādio

gel adeira

televisão

liquidificador

toca-disco

batedeira de bolo

mäquina de lavar

enceradeira

- Qual a frequēncia com que costuma ver televisão, ouvir rādio? Compra jornal? Revistas?

- Quem resolve o que deve ser feito com a renda da família?

- Onde, quando e quem faz as compras do que a famīi ia precisa?

- E preciso ir à cidade para comprar o que precisam ou tem quem venha no sîtio?. Tem venda, armazēm por perto?

- Alguēm na famīilia vai sempre à cidade? Frequência? 0 que vai fazer? 
- Na sua famīilia è costume comprar a prestação? O que?. Estā pagando prestação no momento?

- Precisam comprar al imentos? Quais?

- Compram sabão? De que tipo? Produtos de limpeza?

- Como é feita a compra das roupas na sua famîlia? Compra sō para os que precisam ou quando compra, compra para todos? Frequência?

- Como a senhora ou alguém da sua famîlia escollhe uma peça de roupa?

- As roupas das crianças, dos jovens, dos homens, das mulheres são compradas prontas, mandadas fazer ou feitas em casa?

- Alguēm costura na famīlia?

- As pessoas de sua famīlia costumam fazer diferença nas roupas de trabalhar, sair, passear?

- As roupas de trabalhar são feitas especialmente para o trabalho ou são aproveitadas as de sair mais velhas?

- E importante a pessoa se vestir bem? Por que?

- Acha que as pessoas da cidade se vestem diferente das pessoas da roça? Como?

- Se morassem na cidade, as pessoas de sua famīlia precisariam vestir diferente? Por que? Como? 
- O que acha da vida na cidade? E diferente do modo de vida da roça? Por que?

- Acha que a vida na cidade é melhor ou pior do que na roça?

- Quem mora na cidade tem mais conforto? Por que? 0 que a senhora acha que é conforto?

- Se sua famīlia fosse morar na cidade, a senhora acha que a vida ia ser diferente? Mudaria alguma coisa? 0 que? Por que? 